\title{
Transparent exopolymer particles (TEP), phytoplankton and picocyanobacteria along a littoral-to-pelagic depth-gradient in a large subalpine lake
}

\author{
Cristiana Callieri, ${ }^{1 *}$ J. Salvador Hernández-Avilés, ${ }^{2}$ Ester M. Eckert, ${ }^{1}$ Michela Rogora,,${ }^{1}$ Gabriele Tartari, ${ }^{1}$ \\ Tommaso Sforzi, ${ }^{1}$ Raffaella Sabatino, ${ }^{1}$ Roberto Bertoni ${ }^{1}$ \\ ${ }^{1}$ National Research Council, Water Research Institute, Largo Tonolli 50, 28922 Verbania Pallanza, Italy; ${ }^{2}$ Laboratory of Limnology, \\ UMIEZ, Biology Department, FES Zaragoza, Universidad Nacional Autónoma de México, Mexico City, Mexico
}

\begin{abstract}
Transparent exopolymer particles (TEP) play an important role in the organic carbon cycle of many aquatic systems but the production and distribution of TEP have been studied mainly in the marine environment, neglecting the large oligotrophic lakes. We selected Lake Maggiore, one of the most important freshwater reserve in Northern Italy, to study the horizontal and vertical distribution of TEP and of its possible drivers. Samplings along a transect in the Borromeo basin were performed in May, July and September 2019. Total organic carbon (TOC), TEP, chlorophyll- $a$ (Chl) of different algal groups, picocyanobacteria, bacteria and eukaryotes counting, were measured at six stations and five depths. Our study showed that TEP exhibited a clear vertical heterogeneity from surface to the bottom related to the autotrophic microorganisms that are the main source of TEP and are prevalent in the euphotic zone of the lake. On the other hand, TEP was fairly evenly distributed along the horizontal transect from littoral to pelagic zone, although patches were present in spring, when TEP concentrations were low. In contrast to TEP, TOC and to a lesser extent $\mathrm{Chl}$ and bacteria showed horizontal heterogeneity, in some months. In Lake Maggiore TEP indeed was an important fraction of total organic carbon (TOC), making up to 54\% of TOC (in carbon units: $\left.910 \mu \mathrm{g} \mathrm{C} \mathrm{L}^{-1}\right)$ and it was significantly correlated with Chl. The highest TEP concentration $\left(1.44 \mathrm{mg} \mathrm{GX}\right.$ eq L $\left.\mathrm{L}^{-1}\right)$ was measured in September 2019, in coincidence with an episode of superficial foam appearance. Considering the biomass as Chl concentrations, the algal group mostly related to TEP was that of brown algae, particularly diatoms; but considering the numbers, the picocyanobacteria and bacteria were more significantly correlated to TEP. The presence of pennate diatoms in May and July, with their TEP-related chlorophyll, did not produce TEP in as high concentration as that observed in September in the presence of centric diatoms and of very high numbers of picocyanobacteria and bacteria.
\end{abstract}

\section{INTRODUCTION}

Transparent exopolymer particles (TEP) are operationally defined as acidic polysaccharides retained on 0.4 $\mu \mathrm{m}$ pore-size polycarbonate filters and visible when stained with Alcian Blue (Passow, 2002a). TEP are included in the larger category of extracellular polymeric substances (EPS) but are not in the dissolved phase, they rather exist as non-living and discrete particles (Alldredge et al., 1998; Liu et al., 2018).

The study of TEP in the field has focused on its abun-

Corresponding author: cristiana.callieri@irsa.cnr.it

Key words: TEP horizontal distribution; foams; picocyanobacteria and phytoplankton distribution; Lake Maggiore; littoral-pelagic transects.

Received: 12 April 2021.

Accepted: 15 may 2021.

This work is licensed under a Creative Commons Attribution NonCommercial 4.0 License (CC BY-NC 4.0).

${ }^{\circ}$ Copyright: the Author(s), 2021

Licensee PAGEPress, Italy

J. Limnol., 2021; 80(3):2021

DOI: 10.4081/jlimnol.2021.2021 dance and on the main drivers to forecast its distribution primarily in the marine environment, from the Antarctic Southern Ocean to the Atlantic and Mediterranean Sea (Corzo et al., 2005; Prieto et al., 2006; Ortega-Retuerta et al., 2009a; Zamanillo et al., 2019a), even though this component of total organic carbon (TOC) can reach high concentrations particularly in inland waters (de Vicente $e t$ al., 2010). In freshwaters one of the most common TEP aggregates are referred to as "lakes snow" in analogy to their marine counterpart known as "marine snow" (Silver et al., 1978). Lake snow was studied in the large Lake Constance and considered as a significant carbon sink (Grossart and Simon, 1998a) and as a site for intense microbial decomposition (Grossart and Simon, 1998b). In north temperate lakes, TEP concentration measured as gum xanthan equivalent, (GX eq) can range 36-1462 $\mu \mathrm{g}$ $\mathrm{L}^{-1}$ (de Vicente et al., 2010). In the deep oligotrophic Lake Maggiore even higher concentrations have been measured in autumn (3.3 mg GX eq L $\mathrm{L}^{-1}$ at $5 \mathrm{~m}$ in September 2018, Callieri et al., 2019a).

Furthermore, in a three-year study on Lake Maggiore, TEP concentration exhibited a clear seasonal variability mirroring the one of chlorophyll- $a(\mathrm{Chl})$. In addition, TEP concentration is significantly correlated to picocyanobacteria abundance (Callieri et al., 2017).

It is recognised that TEP plays an important role in the organic carbon cycle in aquatic systems (Engel et al., 2004; Passow and Carlson, 2012), even if it can come 
from different sources and organisms responsible for its production can vary from one environment to another according to different trophic and hydrological conditions. On the one hand, it has been shown that marine aggregates can be formed by abiotic processes from colloidal precursors (Passow, 2000), by turbulence (Pedrotti et al., 2010) or by UV radiation (Ortega-Retuerta et al., 2009b). It is well established that sticky polysaccharide precursors are excreted by various planktonic organisms during their growth and decomposition phases, so that biotic and abiotic causes are often interacting in the formation of aggregates (Passow, 2002a).

Phytoplankton was considered, especially in marine environments, the most important source of TEP (Passow and Alldredge, 1994). In particular, the main TEP producers were identified as: marine diatoms (Passow, 2002b), marine and freshwater cyanobacteria (Grossart et al., 1998; Berman-Frank et al., 2007; Deng et al., 2016; Callieri et al., 2017) and dinoflagellates (Passow and Alldredge, 1994; Alldredge et al., 1998). Other organisms, such as zooplankton (Prieto et al., 2001) or macroalgae (Thornton, 2004), have also been reported as secondary sources of TEP. Heterotrophic bacteria have also proven important in the production of TEP, mainly because they can attach themselves to algal cells and form a microzone that can be the site of production of extracellular substances that mediate aggregation (Grossart et al., 2006; Gärdes et al., 2011). Alternatively, bacteria can also release high amounts of polysaccharides and have a direct role in TEP formation in the sea (Ortega-Retuerta et al., 2010).

Other microorganisms directly involved in TEP production include picocyanobacteria. There are evidences of the importance of picocyanobacteria-TEP relation both in marine and freshwaters: in the oligotrophic oceans Prochlorococcus sp. has been identified as a possible relevant source of TEP (Iuculano et al., 2017) and in the oligotrophic Lake Maggiore Synechococcus spp. abundance significantly correlated to TEP concentration (Callieri et al., 2017). Different cyanobacteria genera can produce TEP (Trichodesmium, Berman-Frank et al., 2007; Anabaena, Bittar and Vieira, 2010; Crocosphaera, Sohm et al., 2011; Synechococcus, Deng et al., 2016, Callieri et al., 2019b). In laboratory experiments, under oxidative stress conditions Vulcanococcus limneticus produced TEP to contrast the UVR-PAR detrimental effect and formed microcolonies or larger aggregates (Callieri et al., 2019b). TEP formation and Synechococcus cell aggregation have also been related to other stress conditions like nutrient limitation (Deng et al., 2016). When a phytoplankton bloom declines, the excretion of mucus by senescent cells favours the formation of sticky aggregates (Schuster and Herndl, 1995). Therefore, cells in decay or during the Programmed Cell Death (PCD) pathways induced by a stress, result in aggregate formation, high caspase-specific activ- ity and TEP production (Bidle, 2015; Nissimov and Bidle, 2017; Thornton and Chen, 2017).

Taking into account the enormous importance of picocyanobacteria in the biogeochemical cycles of aquatic environments (Flombaum et al., 2013), we consider it crucial to study their role in TEP production particularly in the large deep lakes that constitute an important freshwater reserve for the planet. As study site we selected Lake Maggiore, one of the largest and deepest subalpine lakes in Europe. This lake is monitored since the eighties, including a new monitoring programme on TEP temporal and spatial dynamics funded by the International Commission for the Protection of Italian-Swiss Waters (CIPAIS) initiated in 2013. The results showed that the annual average concentration of TEP has increased about three times over eight years (CIPAIS Reports). These results are derived from the study, carried out between 2013 and 2020, of the variability of TEP concentration over time and with depth at the deepest sampling station in Lake Maggiore. Given the presence of foams in littoral areas during the months of high TEP concentration, it could be assumed that there is a horizontal gradient of TEP and related parameters. As data on the horizontal distribution of TEP and related parameters are lacking in the literature, we decided to study the TEP distribution in a littoral-pelagic gradient in relation to the TOC, and $\mathrm{Chl}$ concentration of the most important algal groups and to the picocyanobacteria abundance. Therefore, we carried out a series of samplings along a transect from littoral to pelagic zone ( $2 \mathrm{~km}$ from the shore) in the Borromeo basin of Lake Maggiore. Three sampling campaigns were carried out in different periods of the year (May, July and September 2019) to measure the variations of TEP, TOC, main physical and chemical parameters in relation to picocyanobacteria abundance, and Chl of the main phytoplankton groups. The aims of this study were: 1) to investigate the possible presence of a littoral-pelagic gradient of TEP, TOC, Chl concentration and autotrophic organisms; 2) to ascertain in detail to which algal groups TEP production is most correlated; 3) to deepen the knowledge about the relationship between picocyanobacteria and TEP.

\section{METHODS}

\section{Site description and sampling}

Lake Maggiore $\left(45^{\circ} 55^{\prime} \mathrm{N}, 8^{\circ} 32^{\prime} \mathrm{E}\right.$, lake area $212 \mathrm{~km}^{2}$, $\mathrm{Z}_{\max } 372 \mathrm{~m}$ ) is a large, deep lake located in the subalpine Northern Italy lake district. Its chemical, physical and biological characteristics are well studied (Ambrosetti et al., 2003; Bertoni et al., 2010; Morabito et al., 2012; Salmaso and Mosello, 2010; Salmaso et al., 2020) and the lake is now in oligo-mesotrophic conditions, with annual average 
total phosphorus around $12 \mu \mathrm{g} \mathrm{L}^{-1}$ (Rogora et al., 2018).

Since 1980 , the lake is included in a monitoring program of biological, chemical and physical variables, with monthly/fortnightly samplings along the whole water column, funded by CIPAIS. Lake Maggiore is also a research site within the LTER (Long-Term Ecological Research) network (Site LTER_EU_IT_045).

Sampling was performed in the Borromeo Basin on three occasions during 2019: 21 May, 16 July and 18 September, in an area of the lake not subject to direct inputs of inflowing waters. In a distance of up to $2 \mathrm{~km}$ from the coast, 6 sampling stations (St.) and 5 depths along the profile were selected (Tab. 1) to obtain a rather detailed distribution of the selected parameters. On each occasion six sampling sites in a horizontal transect were selected, according to isobaths $(20,30,50,70,100,120 \mathrm{~m})$ plus one from the shore (St.0 at $0.5 \mathrm{~m}$ ) to finally obtain sampling for littoral, mesopelagic and pelagic zones (Tab. 1). At St. 1 samples were taken at $0.5,5,10$, and $1 \mathrm{~m}$ from the bottom; at St. 2, 3, 4, 5, 6 samples were taken at 0.5, 5, 10, 15 and $1 \mathrm{~m}$ from the bottom (Tab. 1).

The analyses of Total Organic Carbon (TOC) and Transparent Exopolymer Particles (TEP) were performed at the six stations along the transect plus one from the shore and at different depths (30 samples). At all depths counting of picocyanobacteria, heterotrophic bacteria and eukaryotes, photosynthetic efficiency $\left(\mathrm{F}_{\mathrm{v}} / \mathrm{F}_{\mathrm{m}}\right)$ and $\mathrm{Chl}$ analyses were performed (see specific paragraphs for details).

At station 0, 2, 4 and 6 chemical analyses were performed on water samples collected at five different depths (Tab. 1). In total 48 samples were analyzed for chemical variables (in the three months). Sampling and analytical procedures were the same currently used in the CIPAIS monitoring programs of Lake Maggiore (Rogora et al., 2019).

\section{In situ measurements and chemical parameters}

Water temperature, electrical conductivity, $\mathrm{pH}$, dissolved oxygen and $\mathrm{Chl}$ were measured in situ (underwater multiparametric probe IDRONAUT OS 316, Idronaut) in the six stations from surface to bottom. In situ Chl was also measured from surface to $30 \mathrm{~m}$ (the length of the cable) by a multi-wavelength probe (TS-16-12 Fluoroprobe, bbeMoldaenke $\mathrm{GmbH}$, Kronshagen, Germany) to get not only the total $\mathrm{Chl}$ concentration but also that of the different algal classes. The Fluoroprobe measures $\mathrm{Chl}$ fluorescence excited at six different wavelengths (370, $470,525,570,590,610 \mathrm{~nm})$ and was calibrated to differentiate between "spectral" groups of phytoplankton on the basis of their relative $\mathrm{Chl}$ fluorescence intensity at $680 \mathrm{~nm}$ emission. The UV LED (370 nm) measures the fluorescence of CDOM (Chromophoric Dissolved Organic Matter) to correct the signal of the other channels. The instrument divides phytoplankton in green algae (chlorophytes: Chlorophyceae, Prasinophyceae and Euglenophyceae); xanthophyll-containing brown algae (Dynophyceae, diatoms: Bacillariophyceae, Fragillariophyceae, Mediophyceae; and Chrysophyceae); blue-green $P C$ (Cyanophyceae phycocyanin-rich), blue-green PE (Cyanophyceae phycoerythryn-rich), and Cryptophyceae with $\mathrm{Chl} a, \mathrm{Chl} c$ and phycobiliproteins.

The following chemical variables were analysed on water samples: $\mathrm{pH}$, electrical conductivity (potentiometric methods), total alkalinity (Gran's titration), soluble reactive (RP) and total phosphorus (TP), ammonium (N-NH${ }_{4}$, total nitrogen (TN), (spectrophotometry, UV-VIS spectrophotometer SAFAS UV mc ${ }^{2}$ ), reactive silica ( $\mathrm{Si}$ ) (continuous flow analysis; QuAAtro, SEAL Analytical) nitrate $\left(\mathrm{N}-\mathrm{NO}_{3}\right.$; ion chromatography, ion analyzer Dionex series ICS3000). All the analyses were performed according to standard methods for freshwater samples (APAT, IRSACNR, 2003; APHA, AWWA, WEF, 2012).

\section{Total organic carbon (TOC) and transparent exopolymer particles (TEP)}

TOC concentration was measured using a total organic carbon analyser equipped with ASI-L autosampler (Shimadzu, TOC-L High-Sensitivity Model). The organic carbon is oxidized at $680^{\circ} \mathrm{C}$ in $\mathrm{O}_{2}$ stream and the resulting

Tab. 1. Sampling zones, stations, distance from the shore, maximum depth of the stations at the different isobaths and sampling depths along the transect in the study performed in the Borromeo Basin of Lake Maggiore, 2019. In bold are marked the stations and depths from where samples were also taken for chemical analyses.

\begin{tabular}{|c|c|c|c|c|c|c|c|}
\hline \multirow{2}{*}{$\begin{array}{l}\text { Zones } \\
\text { Stations }\end{array}$} & \multicolumn{3}{|c|}{ Littoral } & \multicolumn{2}{|c|}{ Mesopelagic } & \multicolumn{2}{|c|}{ Pelagic } \\
\hline & $\mathbf{0}$ & 1 & 2 & 3 & 4 & 5 & 6 \\
\hline Distance from shore $(\mathrm{m})$ & 1 & 300 & 380 & 1075 & 1315 & 1820 & 1960 \\
\hline Isobaths & 0.5 & 20 & 30 & 50 & 70 & 100 & 120 \\
\hline \multirow[t]{5}{*}{ Sampling depths (m) } & 0.5 & 0.5 & 0.5 & 0.5 & 0.5 & 0.5 & 0.5 \\
\hline & & 5 & 5 & 5 & 5 & 5 & 5 \\
\hline & & 10 & 10 & 10 & 10 & 10 & 10 \\
\hline & & bottom & 15 & 15 & 15 & 15 & 15 \\
\hline & & & bottom & bottom & bottom & bottom & bottom \\
\hline
\end{tabular}


$\mathrm{CO}_{2}$ is measured with a non-dispersive infrared detector (NDIR). Two replicates for each sample were analysed running five analyses per sample.

The concentration of TEP was measured spectrophotometrically as absorbance at $787 \mathrm{~nm}$ in a $1 \mathrm{~cm}$ cell against distilled water as reference (Alldredge et al., 1993). Samples were filtered onto polycarbonate membranes $(0.4 \mu \mathrm{m}$ pore size $)$ under low vacuum $(<10 \mathrm{mbar}$, $150 \mathrm{~mm} \mathrm{Hg}$ ), stained with $500 \mu \mathrm{l}$ of $0.22 \mu \mathrm{m}$ pre-filtered $0.02 \%$ Alcian Blue (8GX, Fluka) aqueous solution, in $0.06 \%$ glacial acetic acid ( $\mathrm{pH} 2.5$ ) for 30 second (Alldredge et al., 1993). After staining, the membranes were rinsed once with MQ water, and then transferred to glass vials. An aliquot of $6 \mathrm{ml}$ of $80 \%(\mathrm{v} / \mathrm{v})$ sulphuric acid was added to the glass vials and the membranes were left immersed for $2 \mathrm{~h}$.

The concentration of TEP was expressed as gum xanthan (GX) equivalent ( $\mu \mathrm{g} \mathrm{GX}$ eq $\mathrm{L}^{-1}$ ) following Passow and Alldredge (1995). From the TEP data as $\mu \mathrm{g}$ GX eq $\mathrm{L}^{-}$

${ }^{1}$ we calculated TEP concentration as $\mu \mathrm{g} \mathrm{C} \mathrm{L}^{-1}$ using the conversion factor of 0.63 proposed by Engel (2004) and recently used also by Berman-Frank et al. (2016).

\section{Cell counting}

Samples were immediately fixed with filtered formaldehyde $(0.2 \mu \mathrm{m}$ pore size membrane, $1 \%$ final concentration) and stored at $4{ }^{\circ} \mathrm{C}$ in the dark. Flow cytometer Accuri C6 (Becton Dickinson, Oxford, UK), equipped with a $20 \mathrm{~mW} 488 \mathrm{~nm}$ Solid State Blue Laser and a 14.7 $\mathrm{mW} 640 \mathrm{~nm}$ Diode Red Laser, was used to quantify picocyanobacteria and bacteria.

Picocyanobacteria, that in Lake Maggiore are mainly composed by Synechococcus and Cyanobium genera (Callieri et al., 2012), were quantified using light scattering signals (forward and side light scatter named FSC-H and SSC-H, respectively), orange fluorescence (FL2-H channel $=585 / 40 \mathrm{~nm}$ ) and red fluorescence (FL3-H channel $>670$ $\mathrm{nm}$ and FL4-H channel 675/25). The density plots of FL2$\mathrm{H} v$ s FL3-H allowed for the optimal gating design and the quantification of the phycoerythrin-rich (PE) and phycocyanin-rich (PC) Synechococcus cells (Callieri et al., 2016). Larger autofluorescent cells (mainly eukaryotic nanoplankton) (Eukaryote) that form a distinct cloud in the cytograms with higher Chl signal were also counted.

The overall bacterial abundance was determined by following the common procedures after staining with SYBR Green I (1:10000 final concentration; Thermofisher Scientific) (Gasol and Morán, 2015). All data were acquired at a pre-set flow rate of $35 \mu \mathrm{L} \mathrm{min}^{-1}$, in order to keep the number of total events below 1000 per second. The BD Accuri C6 resident software (v. 1.0.264.21) was used for cytogram gating and data processing.

When necessary, for the presence of colonial or aggregated picocyanobacteria (in September) the sample was counted twice, before and after sonication, 3 mins at low energy, by an ultrasonic processor UP200S (Hielscher Ultrasound Technology).

\section{Chlorophyll- $a$ and photosynthetic activity measurement}

Chl concentration was measured in situ using FluoroProbe, IDRONAUT OS 316 CTD (see paragraph on in situ measurements), and in laboratory measuring the discrete samples by Pulse-Amplitude-Modulation Phytoplankton Analyzer (PhytoPAM, Heinz Walz, GmbH, Effeltrich, Germany). PhytoPAM was equipped with the Optical Unit ED 101US/MP, the phyto ML (25 measuring LED in the 4 wavelengths and 12 actinic LED $655 \mathrm{~nm}$ ), and the phyto AL (37 actinic LED 655nm) (Schreiber et al., 1986). The $\mu \mathrm{g} \mathrm{Chl-} a \mathrm{ml}^{-1}$ was obtained using specific Chl calibration as reference (performed by Walz H.) and reference spectra were obtained using pure cultures of blue, green and brown algae (performed by Walz H.). Also PE and PC Synechococcus pure cultures were also used to obtain specific reference spectra.

In particular, PhytoPAM was used to estimate the photosynthetic activity through the assessment of the effective quantum yield of energy conversion at the reaction centers of photosystem II (PSII) using saturation pulses. The maximal quantum conversion efficiency of PSII as $\mathrm{F}_{\mathrm{v}} / \mathrm{F}_{\mathrm{m}}$ ratio in dark-adapted samples (Genty et al., 1989) was measured for all the samples.

\section{Statistical analyses and maps}

The contour maps of TOC, TEP and Chl concentrations and of PC, PE, bacteria and eukaryote abundance along the transect were made using Surfer 16 (Golden Software).

The effect of the various phytoplankton related measures on TEP abundance was tested separately for total Chl, $\mathrm{Chl}$ assigned to either green algae, cyanobacteria, brown algae and cryptophytes as measured by fluoroprobe and for the abundance of PE, PC and eukaryotes as measured by flow cytometry. Bacterial abundance was not included in the models because it strongly correlated with the abundance of PE (Pearson's correlation $\mathrm{R}^{2}=0.86$ ). Linear models were made for the whole dataset and for each sampling date separately. For the whole dataset the sampling date was used as a random effect using mixed effect models (lmer) with the package lmerTest (Kuznetsova et al., 2017).

The effect of space in terms of horizontal (sampling station) and vertical (sampling depth) distribution on each of the measured parameters was evaluated using linear models as described for TEP. Output is depicted using the Anova function of the car package (Fox and Weisberg, 2019). Multivariate statistics were applied using a canonical correspondence analysis (CCA) employing vegan package 
2.5.6 (Oksanen et al., 2019) in R (R Core Team, 2019) to evaluate the relationships between the physical and chemical variables and the abundance of the quantified microbial groups. CCA was performed for each month: May, July, and September as well as for the three months combined. The constraining variables used were: depth, transparent exopolymeric particles (TEP), total chlorophyll (T Chl), dissolved inorganic carbon (DIC), total organic carbon (TOC), total nitrogen (TN), nitrate $\left(\mathrm{N}^{-\mathrm{NO}_{3}}\right)$, total phosphorus $(\mathrm{TP})$, reactive silica $(\mathrm{Si})$, temperature, dissolved oxygen (DO), photosynthetic active radiation (PAR) and $\mathrm{pH}$. From these initial ordinations, models were built by permutation $(\mathrm{n}=1000)$ using the ordistep method from vegan. After selecting the significant variables $(p<0.05) \mathrm{CCA}$ was further applied. To test the significance of each ordination anova.cca function from the vegan package was used (permutations $=10000$ ).

\section{RESULTS}

\section{Physical and chemical variables}

Maps and profiles of water temperature (Fig. 1S) and dissolved oxygen (DO) (Fig. 2S) showed a uniform distribution at the different stations. In May, temperature decreased from $12.6-12.8^{\circ} \mathrm{C}$ at the surface to $6.9-7.0^{\circ} \mathrm{C}$ at the bottom, with the steepest gradient between 10 and 15 $\mathrm{m}$ depth; DO was around $10 \mathrm{mg} \mathrm{L}^{-1}$ in the surface layers, slightly increased at $10 \mathrm{~m}$ depth and then decreased regularly with depth until $8.0 \mathrm{mg} \mathrm{L}^{-1}$ at the deepest point of the pelagic station. The thermal gradient increased in July and September, when surface temperature reached $22^{\circ} \mathrm{C}$; the thermocline was around $20 \mathrm{~m}$ depth and DO maxima of about $11 \mathrm{mg} \mathrm{L}^{-1}$ were evident in both periods between 15 and $20 \mathrm{~m}$ depth.

The whole dataset of chemical data resulting from the analyses is provided in Tab. 1S. The vertical profiles of $\mathrm{N}-\mathrm{NH}_{4}, \mathrm{~N}-\mathrm{NO}_{3}, \mathrm{TP}$ and $\mathrm{Si}$ in the different stations and sampling dates are shown in Fig. $1 . \mathrm{N}-\mathrm{NO}_{3}, \mathrm{TP}$ and silica increased with depth in all the three periods, with a more pronounced gradient in summer and autumn, while N$\mathrm{NH}_{4}$ showed an opposite pattern. Concentrations of N$\mathrm{NO}_{3}$ and $\mathrm{Si}$ in surface water were higher in May (about $700 \mu \mathrm{g} \mathrm{L}{ }^{-1}$ and $1.0 \mathrm{mg} \mathrm{L}^{-1}$ respectively), compared to July and September; silica in particular was almost totally depleted in the surface layers in July $\left(0.1-0.2 \mathrm{mg} \mathrm{L}^{-1}\right)$. Concentrations of both $\mathrm{N}-\mathrm{NO}_{3}$ and silica increased with depth in July and September, reaching 750-770 $\mu \mathrm{g} \mathrm{L}^{-1}$ and 1.90 $\mathrm{mg} \mathrm{L}^{-1}$ at the deepest point, respectively. TP showed quite similar patterns in the different periods, with concentration increasing from the surface $\left(6-8 \mu \mathrm{g} \mathrm{L}^{-1}\right.$ in May and 5-6 $\mu \mathrm{g} \mathrm{L}^{-1}$ in July and September) to the bottom, and with the highest values recorded in the pelagic St. 6 (16-17 $\mu \mathrm{g}$ $\left.\mathrm{L}^{-1}\right)$. $\mathrm{N}-\mathrm{NH}_{4}$ concentrations were usually very low (be- tween 5 and $30 \mu \mathrm{g} \mathrm{L}^{-1}$ ), with $\mathrm{N}-\mathrm{NO}_{3}$ as the dominant form of $\mathrm{N}$ in lake water (about $90 \%$ of total $\mathrm{N}$ ). The highest concentrations of $\mathrm{N}^{-\mathrm{NH}_{4}}$ were measured in summer and autumn at 10 and $15 \mathrm{~m}$ in all the stations; below these depths, $\mathrm{N}-\mathrm{NH}_{4}$ concentrations decreased and values in bottom waters were similar or lower than those of the surface layers $\left(5-8 \mu \mathrm{g} \mathrm{L}^{-1}\right)$. In July and September TP also showed higher concentrations at $10 \mathrm{~m}$ depth with respect to the surface at all the stations; the same occurred for $\mathrm{Si}$ in September. In autumn, in the first $5 \mathrm{~m}$ there were conditions of low N-NO $3\left(410 \mu \mathrm{g} \mathrm{L}^{-1}\right)$ and $\mathrm{N}-\mathrm{NH}_{4}\left(6 \mu \mathrm{g} \mathrm{L}^{-1}\right)$ concentrations as well as of TP (around $6 \mu \mathrm{g} \mathrm{L}^{-1}$ ).

As regards the horizontal distribution, epilimnetic concentrations $\mathrm{N}-\mathrm{NO}_{3}$ and $\mathrm{N}-\mathrm{NH}_{4}$ did not show any difference among the stations, while metalimnetic and hypolimetic $\mathrm{N}-\mathrm{NH}_{4}$ concentrations were higher in the pelagic St. 6 with respect to the littoral zone and $\mathrm{N}-\mathrm{NO}_{3}$ showed the opposite pattern. TP in summer tended to be slightly higher in the pelagic zone, while silica concentrations were very similar at the three stations and in the different sampling periods.

\section{TOC and TEP}

TOC showed a decreasing concentration gradient from the surface to the bottom in spring, summer and autumn, more pronounced in the pelagic stations (Fig. 2, Fig. 3S). The biggest differences between the concentrations measured at the surface and near the bottom occurred in September $\left(690 \mu \mathrm{g} \mathrm{C} \mathrm{L}^{-1}\right)$. As the season progressed, the gradient was maintained even though the TOC concentration increased progressively throughout the whole water column. The average TOC concentration (weighted mean over depth and shore distance), along the transect, increased from $1076 \mu \mathrm{g} \mathrm{L}^{-1}$ in May to 1196 and $1720 \mu \mathrm{g} \mathrm{L}{ }^{-1}$ in July and September, respectively. Regarding the horizontal distribution of TOC concentration, organic material showed a decreasing concentration gradient from the pelagic to the littoral zone in May, particularly evident for the layer 0-10 m. In July and September, on the other hand, two regions of higher concentration were clearly evident at the first littoral station (St.1) and the pelagic stations (St. 5 and St. 6). In September at St. 1 the maximum concentration of $2.3 \mathrm{mg}$ $\mathrm{C} \mathrm{L}^{-1}$ was reached at $5 \mathrm{~m}$.

The spatial and temporal distribution of TEP mirrored that of TOC, thus highlighting the close relationship between these two variables (Fig. 3, Fig. 4S). Also for TEP a steep vertical profile was present in September, when 714 and $15 \mu \mathrm{g} \mathrm{C} \mathrm{L}^{-1}$ were measured at 0.5 and $120 \mathrm{~m}$ depth at the pelagic sampling point (St. 6). The average TEP concentration (weighted mean over depth and shore distance), along the transect, increased from $35 \mu \mathrm{g} \mathrm{C} \mathrm{L}^{-1}$ in May to 50 and $236 \mu \mathrm{g} \mathrm{C} \mathrm{L}^{-1}$ in July and September, respectively. However, the seasonal increase in TEP concentration was much higher than that of TOC, with TEP values rising al- 
most tenfold from May to September. In May, the concentration of TEP increased from 57.5 to $98.7 \mu \mathrm{g} \mathrm{C} \mathrm{L} \mathrm{C}^{-1}$ from St. 1 to St.5 (Fig. 4S) whereas in July, the concentrations of
TEP were rather uniforms. In September the values almost triplicated from St. 2 to St. 4 at $5 \mathrm{~m}$ (from 320 to $910 \mu \mathrm{g} \mathrm{C}$ $\mathrm{L}^{-1}$ ) showing a micro-patches distribution.
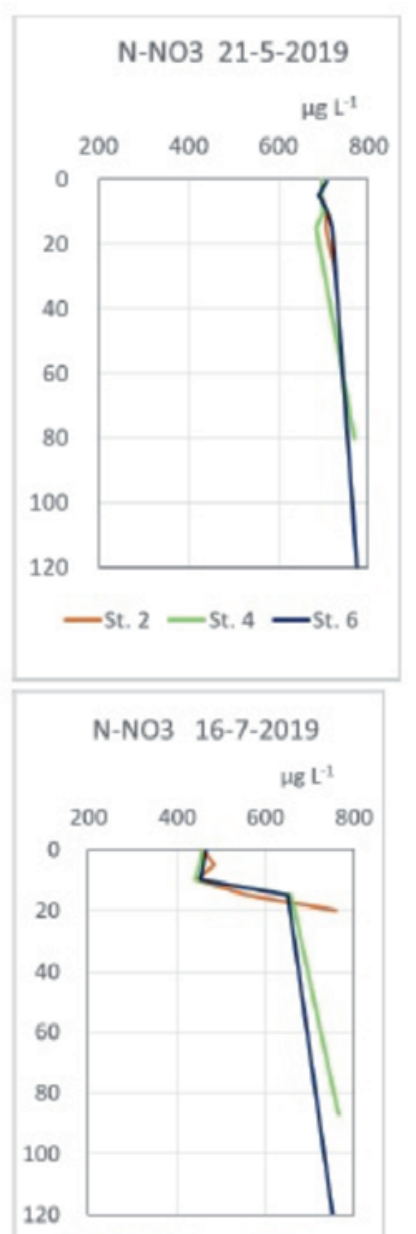

-5t. 2 -5t. 4 -5t. 6

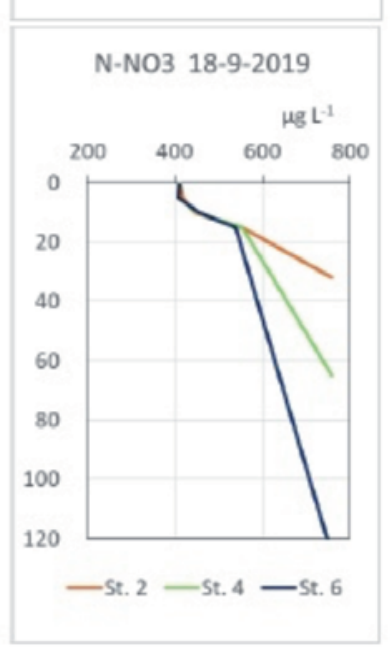

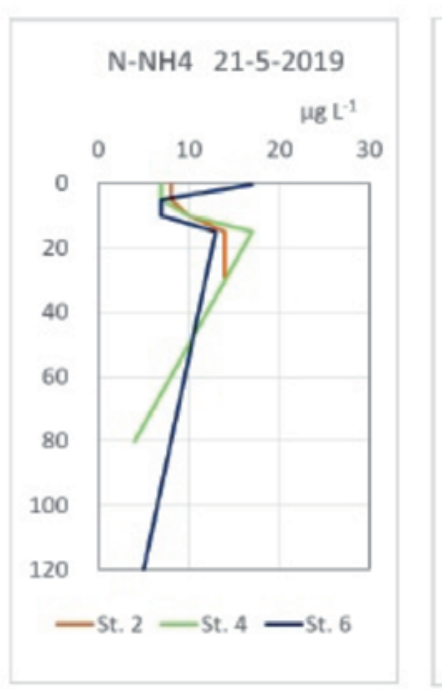
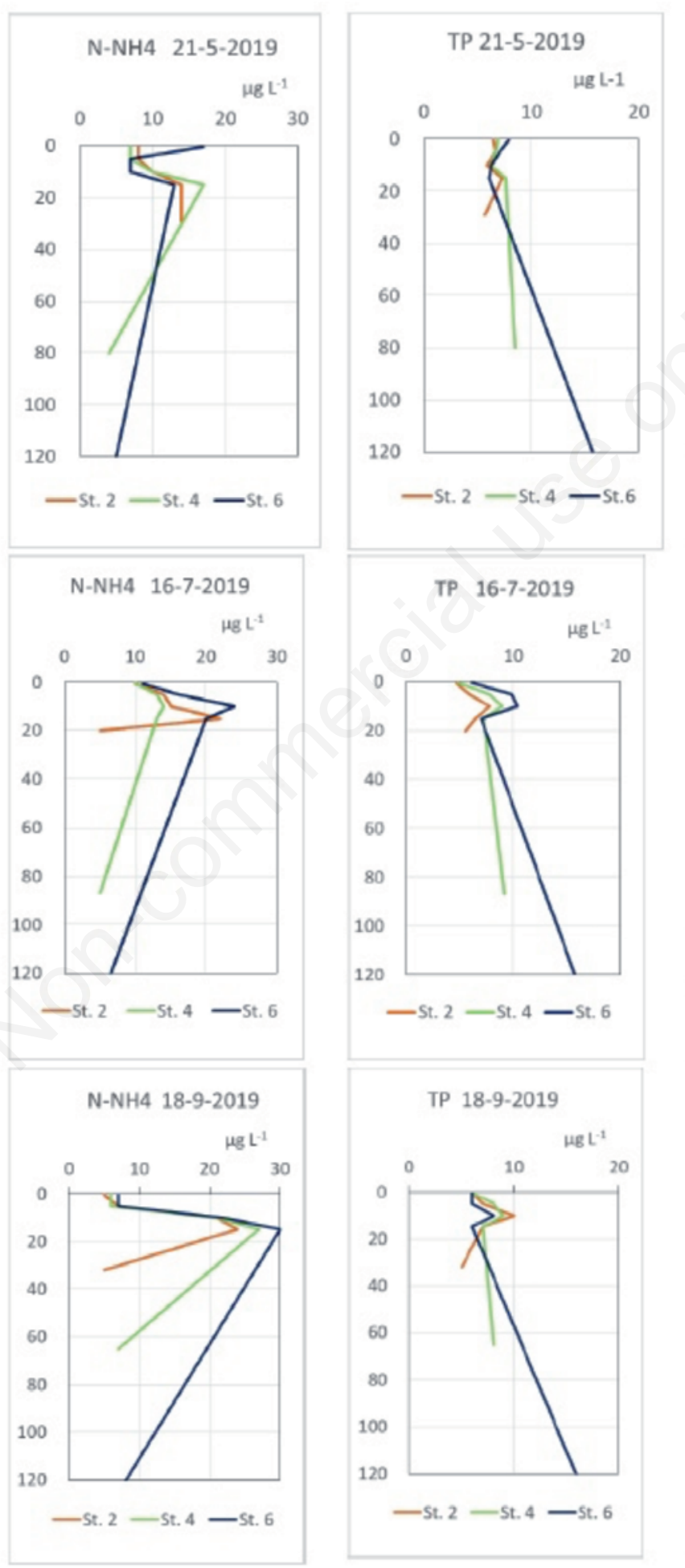
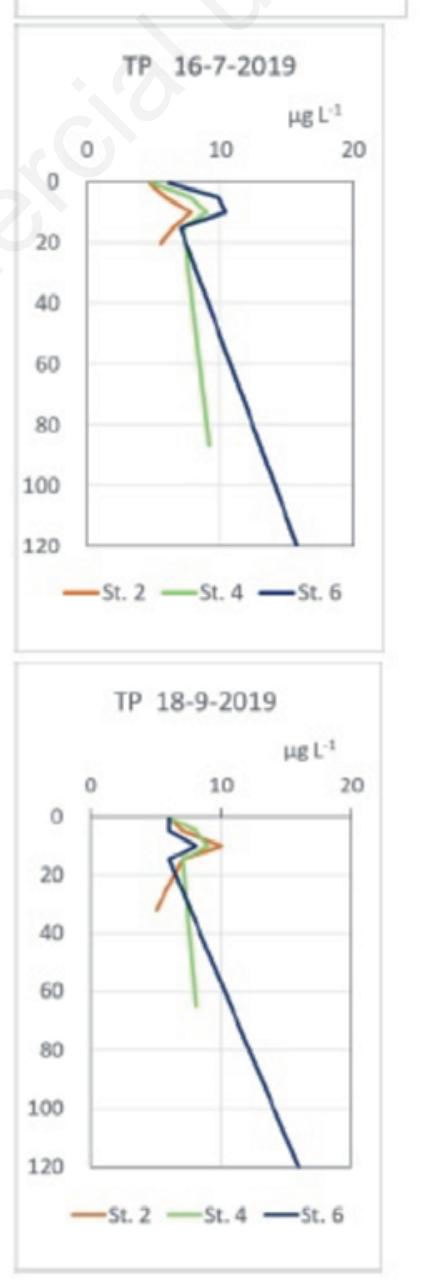

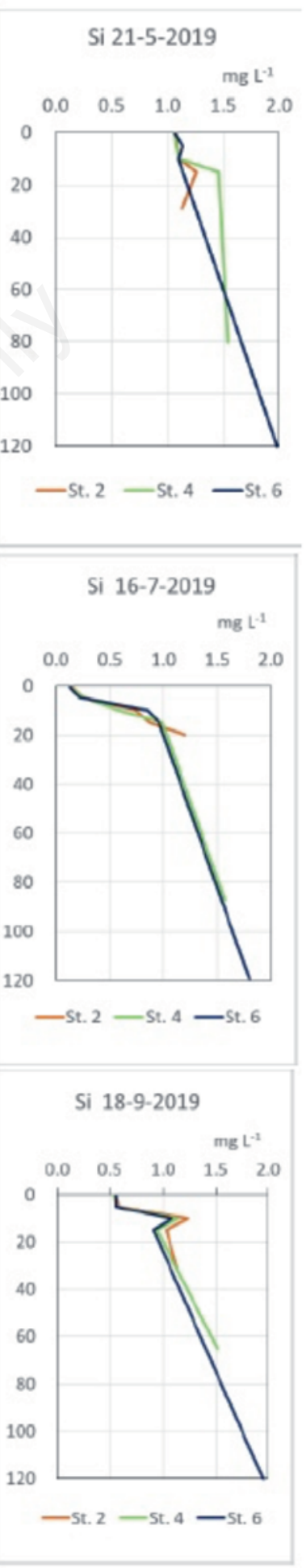

Fig. 1. Profiles of the main nutrient concentrations at Stations 2, 4 and 6, Lake Maggiore, in May, July and September 2019. 


\section{FluoroProbe chlorophyll-a concentrations and photosynthetic efficiency ( $\mathrm{Fv} / \mathrm{Fm})$}

Chl concentrations were measured by three methods and a comparison of the results is presented in the supplementary materials (Fig. 5S).

Here we present the data of the FluoroProbe in a map with the distance from the coast and in vertical profiles (Fig. 4, Fig. 5S). With this probe the weighted mean over depth and shore distance was $1.57 \mu \mathrm{g} \mathrm{Chl} \mathrm{\textrm {L } ^ { - 1 }}$ in May, 4.18 in July and $2.83 \mu \mathrm{g} \mathrm{Chl} \mathrm{L}{ }^{-1}$ in September. The maximum value was reached in July, at $10 \mathrm{~m}$ in St. $3\left(8.13 \mu \mathrm{g} \mathrm{L}^{-1}\right)$. In May, the highest concentrations were measured in the pelagic St. 6 and in St. 4 at 10 and $8 \mathrm{~m}$ respectively, reaching 3.90 and $3.83 \mu \mathrm{g} \mathrm{Chl} \mathrm{L}{ }^{-1}$. From the profiles of the different algal groups the major contribution of the green and brown algae to the total $\mathrm{Chl}$ concentrations was evident (in Fig. 5 are reported only St. 2, 4, 6). The profiles of all the stations are presented in the supplementary materials

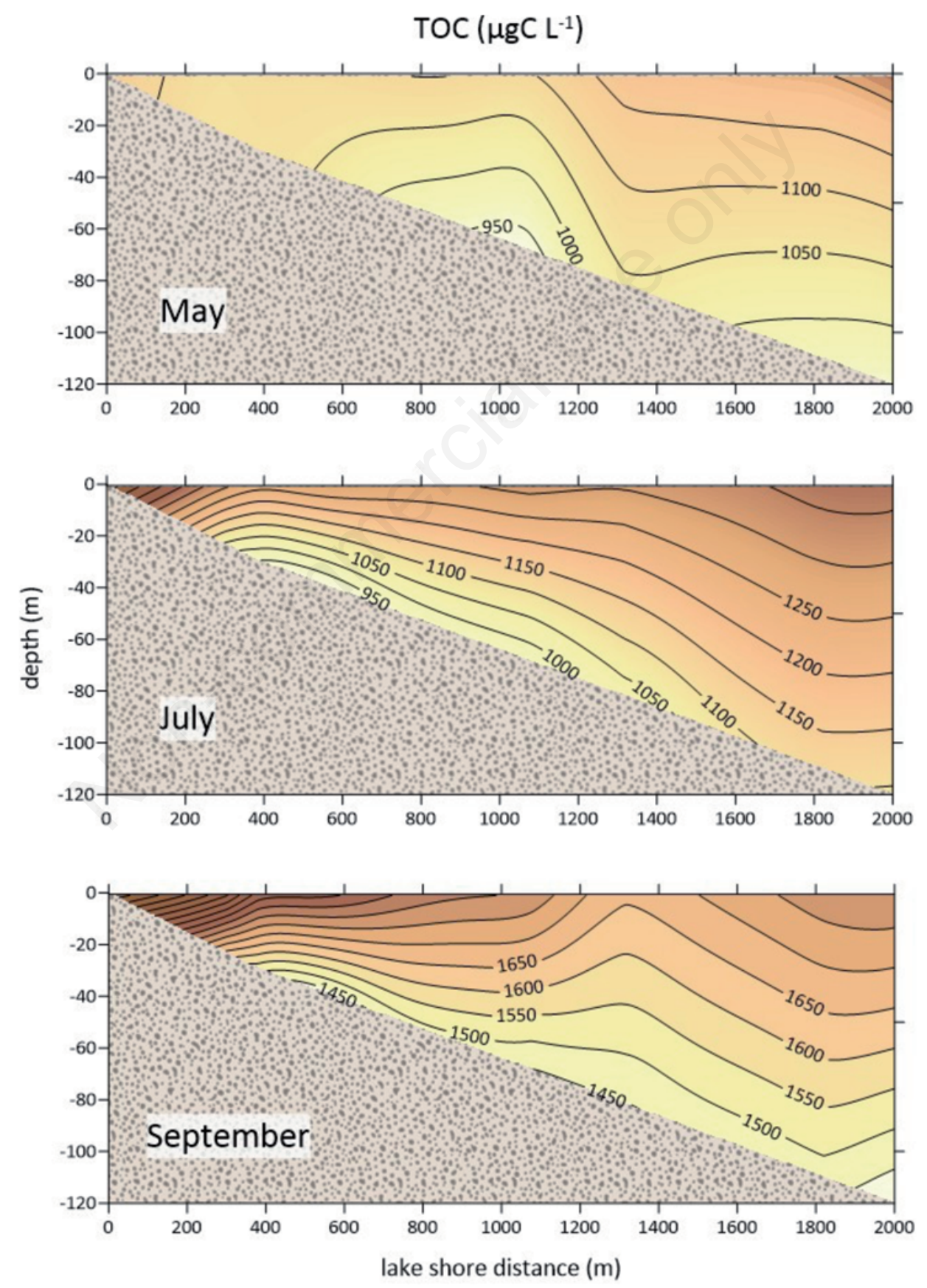

Fig. 2. Total organic carbon (TOC) concentration maps along the transect in Lake Maggiore, 2019. 
(Figs. 6S, 7S, 8S). The cyanobacteria biomass was very

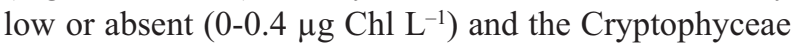
were present all along the profile with a peak at St. 4 near $10 \mathrm{~m}$. The green algae prevailed in the first $6 \mathrm{~m}$ and the brown had the peak at $8-10 \mathrm{~m}$. From the microscopic counting performed in a different date (16-6-2019) in the Borromeo basin it appears that the brown algae were mainly composed by Crysophyceae both at 5 and $15 \mathrm{~m}$ (Fig. 9S). The concentrations near the surface were $<2 \mu \mathrm{g}$

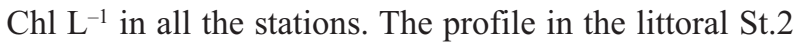

$\operatorname{TEP}\left(\mu g \mathrm{~L} \mathrm{~L}^{-1}\right)$
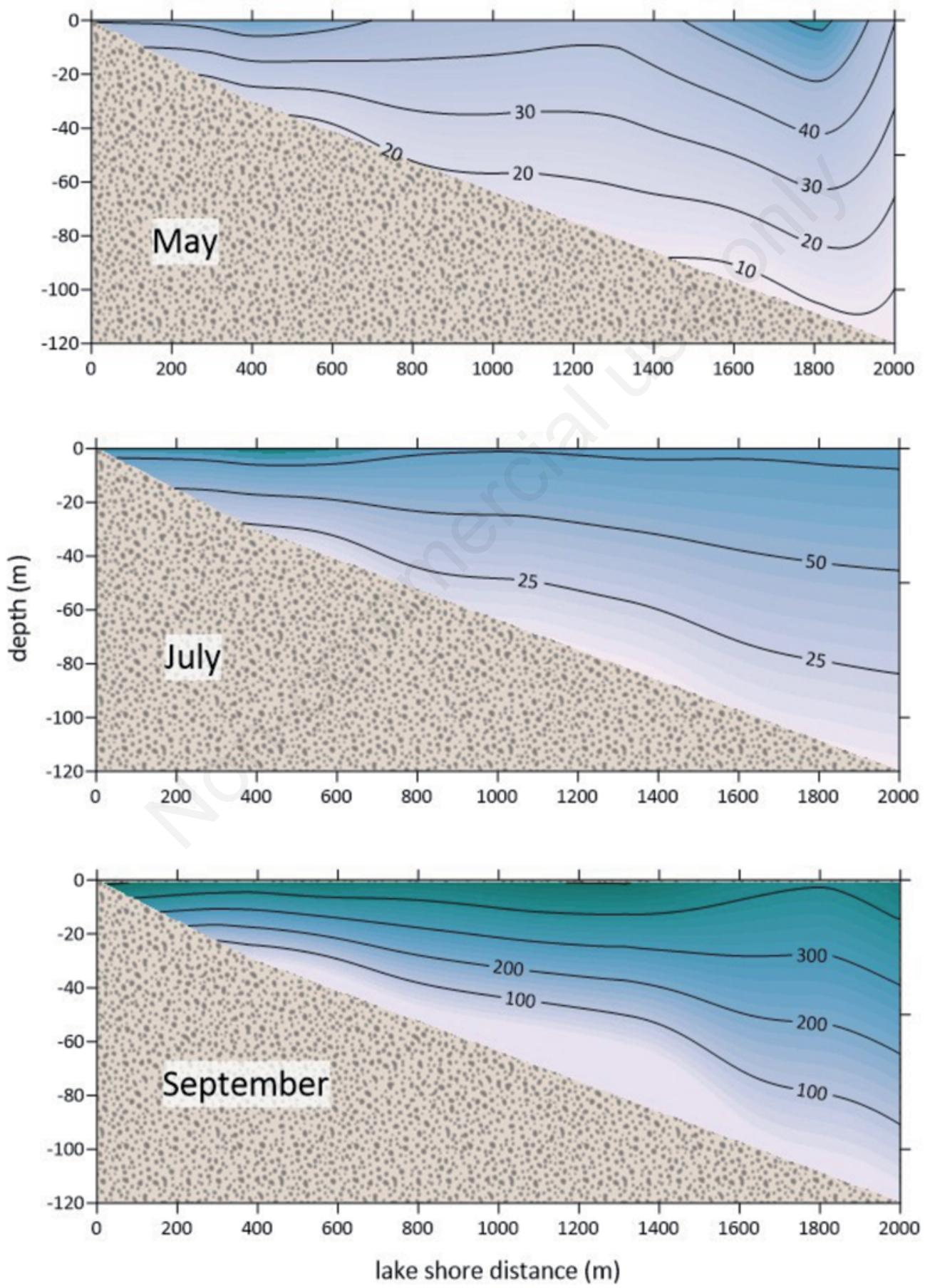

Fig. 3. Transparent exopolymer particles (TEP) concentration maps along the transect in Lake Maggiore, 2019. 
was different from those obtained in the other stations and showed one peak at $2 \mathrm{~m}$ and a second one at $6 \mathrm{~m}$. In the mesopelagic and pelagic stations, below $20 \mathrm{~m}$, the $\mathrm{Chl}$ concentrations were very low $\left(0.1-0.7 \mu \mathrm{g} \mathrm{Chl} \mathrm{L}{ }^{-1}\right)$.
In July the depth profiles of Chl were similar in all the stations and showed two peaks, one at $8 \mathrm{~m}$ with $8 \mu \mathrm{g} \mathrm{Chl}$ $\mathrm{L}^{-1}$ and a second less pronounced peak at $15 \mathrm{~m}$ with around $6 \mu \mathrm{g} \mathrm{Chl} \mathrm{L}^{-1}$ (Fig. 4). This vertical pattern was

\section{Chlorphyll fluoroprobe $\left(\mu \mathrm{g} \mathrm{L}^{-1}\right)$}
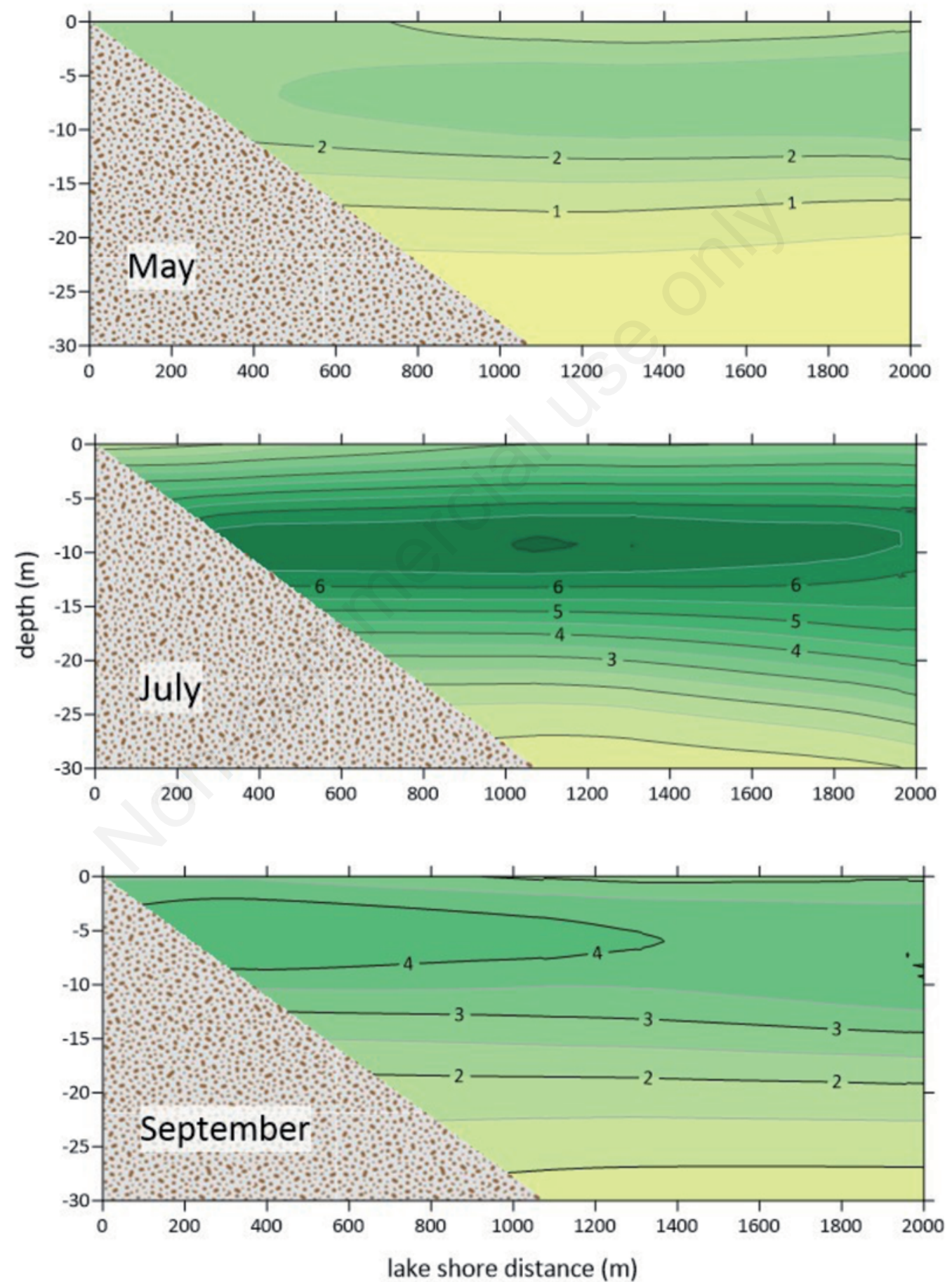

Fig. 4. Chlorophyll- $a$ concentration maps along the transect performed by FluoroProbe in the layer 0-30 $\mathrm{m}$, in Lake Maggiore, 2019. 
more pronounced in the pelagic respect to the littoral stations. Looking at the profiles of the different algal groups we noticed the low signal of the green algae in the first $16 \mathrm{~m}$ with only a small peak at $18-20 \mathrm{~m}$ and the preva- lence of the brown algae in the first $18 \mathrm{~m}$ mainly composed of diatoms (Fig. 5).

In September, there was a general decrease of Chl concentrations with respect to July (Fig. 4). In the pelagic St. 6
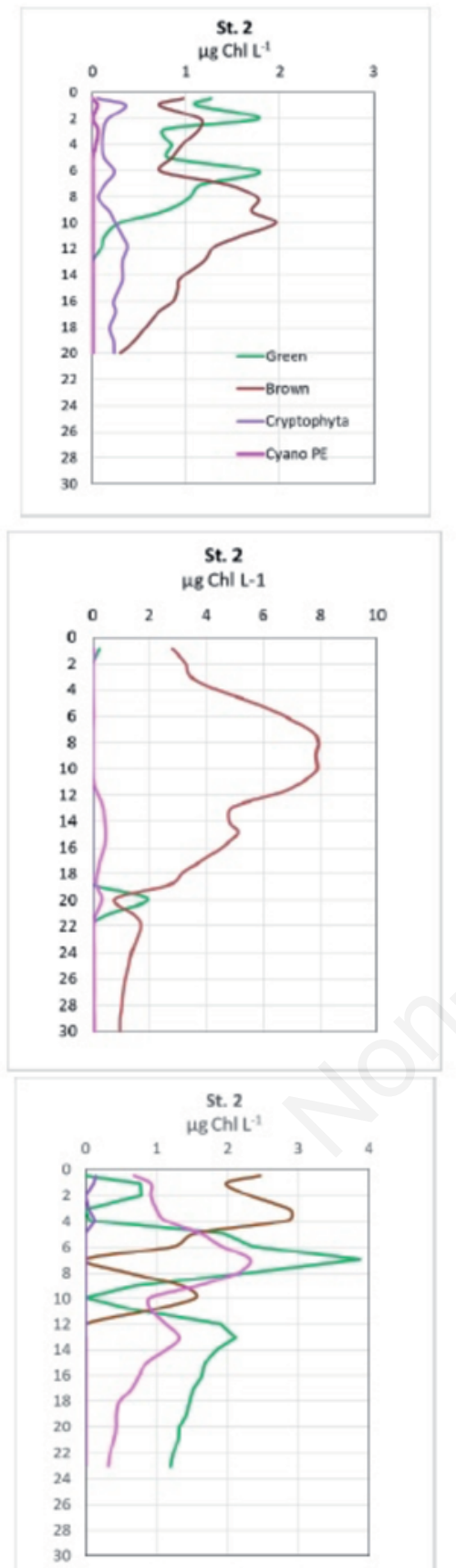
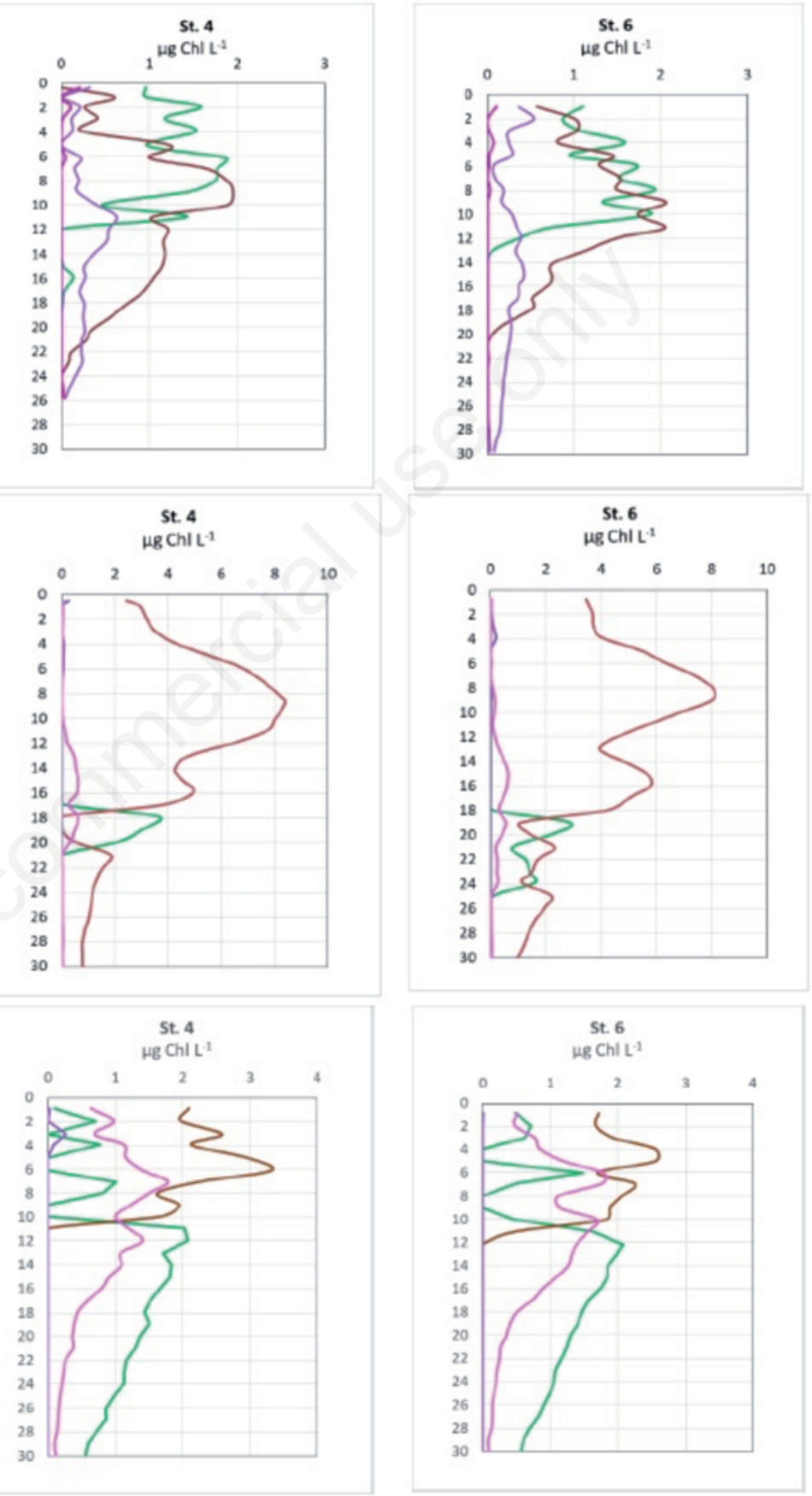

Fig. 5. Profiles of Chlorophyll- $a$ concentrations derived from the different algal groups in the six stations along the transect, in May, June and September 2019, in Lake Maggiore. Green: Chlorophyceae, Prasinophyceae, Euglenophyceae; Brown: Dinophyceae, Bacillariophyceae, Fragillariophyceae, Mediophyceae, Chrysophyceae; Cryptophyta: Cryptophyceae; Cyano PE, Cyanophyceae phycoerythryn-rich. 


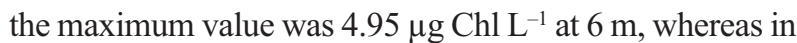
the littoral stations the maximum was $6.19 \mu \mathrm{g} \mathrm{Chl} \mathrm{L}{ }^{-1}$ (St. 2 ) at $7 \mathrm{~m}$. The vertical profiles of the different algal groups showed a situation very different from the other two dates (May and July) with the appearance of Cyanobacteria that were mainly composed by picocyanobacteria in its solitary and colonial forms together with other Chroochoccales and Cryptophyceae (Fig. 5, Figs. 8S and 9S). Diatoms were al-

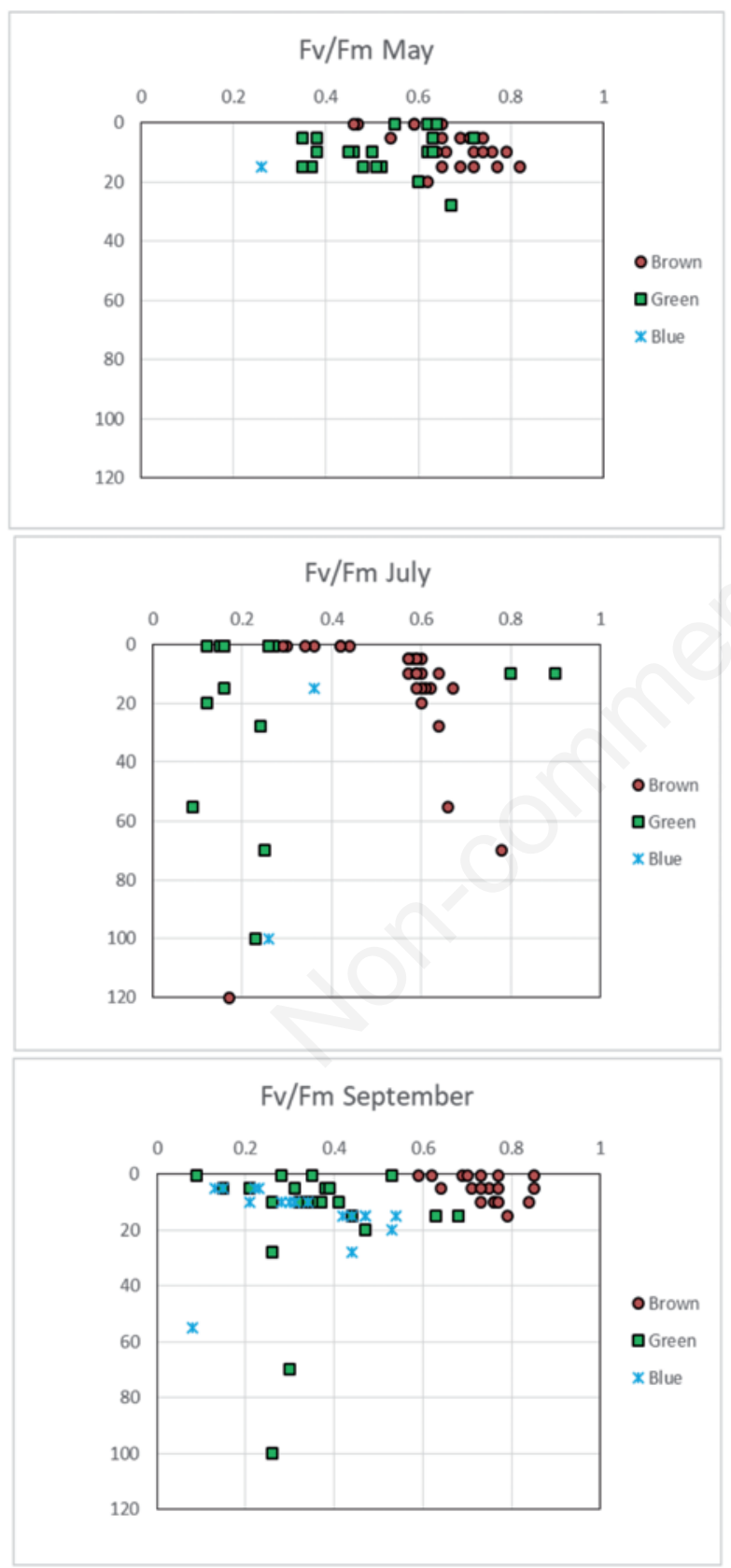

Fig. 6. Photosynthetic efficiency $\left(\mathrm{F}_{\mathrm{v}} / \mathrm{F}_{\mathrm{m}}\right)$ for the three algal groups reported in the legend and measured by PhytoPAM in May, July and September 2019, in Lake Maggiore. ways prevailing in the first five meters but below this depth there was an increase of green algae and picocyanobacteria.

The $\mathrm{F}_{\mathrm{v}} / \mathrm{F}_{\mathrm{m}}$ values, that indicate the photosynthetic efficiency of the different algal groups, showed different results in the different months with the highest values in September (Fig. 6). It was interesting to note that in May there were no measurable values below $20 \mathrm{~m}$, whereas in July and September all the algal groups showed some, even rare, positive values also in the deepest layers. The highest efficiency are presented by diatoms (from 0.6 to $0.9)$, with only two exceptions in July when also green algae were very efficient. The $\mathrm{F}_{\mathrm{v}} / \mathrm{F}_{\mathrm{m}}$ were generally lower in the surface samples and increase in the first 10-20 m.

\section{Flow cytometry counts}

Phycoerythrin-rich (PE) and phycocyanin-rich (PC) Synechococcus cells were counted separately using flow cytometer. PE always prevail over PC and constitute from 90 to $99 \%$ of the total picocyanobacteria count. PE number did not show any clear pattern from St. 1 to St. 6, but oscillated along the horizontal gradient (Fig. 7, Fig. 10S). PC horizontal distribution was more variable than PE with the highest numbers at 5 and $10 \mathrm{~m}$ (Fig. 8, Fig. 11S).

In May PE ranged from 0.7 to $80 \times 10^{3}$ cells $\mathrm{ml}^{-1}$ whereas PC from 0.08 to $3.3 \times 10^{3}$ cells $\mathrm{ml}^{-1}$. There was a pronounced increase of PE and PC number along the season with the highest number in September, when the highest PE abundance was reached at $5 \mathrm{~m}$ in St. $6\left(574 \times 10^{3}\right.$ cells $\left.\mathrm{ml}^{-1}\right)$. Also PC reached the highest abundance in September at $5 \mathrm{~m}$ but in the littoral St. $1\left(14.4 \times 10^{3}\right.$ cells $\left.\mathrm{ml}^{-1}\right)$. The weighted mean of $\mathrm{PE}$ counts over depth and shore distance was $34 \times 10^{3}$ cells $\mathrm{ml}^{-1}$ in May, $82 \times 10^{3}$ cells $\mathrm{ml}^{-1}$ in July and $161 \times 10^{3}$ cells $\mathrm{ml}^{-1}$ in September.

Filamentous and colonial cyanobacteria were present in September mainly at $10 \mathrm{~m}$ (PE in aggregates ranged from 25 to $75 \%$, Fig. 12S). The numbers here presented refer to the sonicated sample. It must be underlined here that in September PE were present in high number up to $15-20 \mathrm{~m}$ in all the stations. In September also PC number increases even at a lower extent and more evidently in the littoral stations.

Bacterial abundances maps and profiles (Fig. 9, Fig. $13 \mathrm{~S}$ ) show a progressive increase in number with the season and a decrease with depth. The weighted mean over depth and shore distance was $1.22 \times 10^{6}$ cells ml $^{-1}$ in May, $1.62 \times 10^{6}$ cells $\mathrm{ml}^{-1}$ in July and $2.59 \times 10^{6}$ cells ml-1 in September. In the littoral stations, in May, the number was higher than in the pelagic stations but in July there was an increase of bacteria in St. 5 and St. 6 at 15 m. In May, the range of bacterial abundance was $0.50-2.15 \times 10^{6}$ cells $\mathrm{ml}^{-1}$ and in July was $0.61-2.55 \times 10^{6}$ cells $\mathrm{ml}^{-1}$. In September the number of bacteria ranged $0.67-4.14 \times 10^{6}$ cells $\mathrm{ml}^{-1}$ with high values rather homogeneous in all the stations, and a peak at St.2. 
Eukaryote abundance profiles are reported in supplementary materials (Fig. 14S). They decreased in number along the season, in May (range 0.16-21.5 $\times 10^{3}$ cells $\mathrm{ml}^{-1}$ ) and July (range $0.19-21.4 \times 10^{3}$ cells $\mathrm{ml}^{-1}$ ) the larger algae were more abundant, while in September when the small picocyanobacteria increased in abundance, eukaryotes decreased (range 0.08-13.7 $\times 10^{3}$ cells $\mathrm{ml}^{-1}$ ).

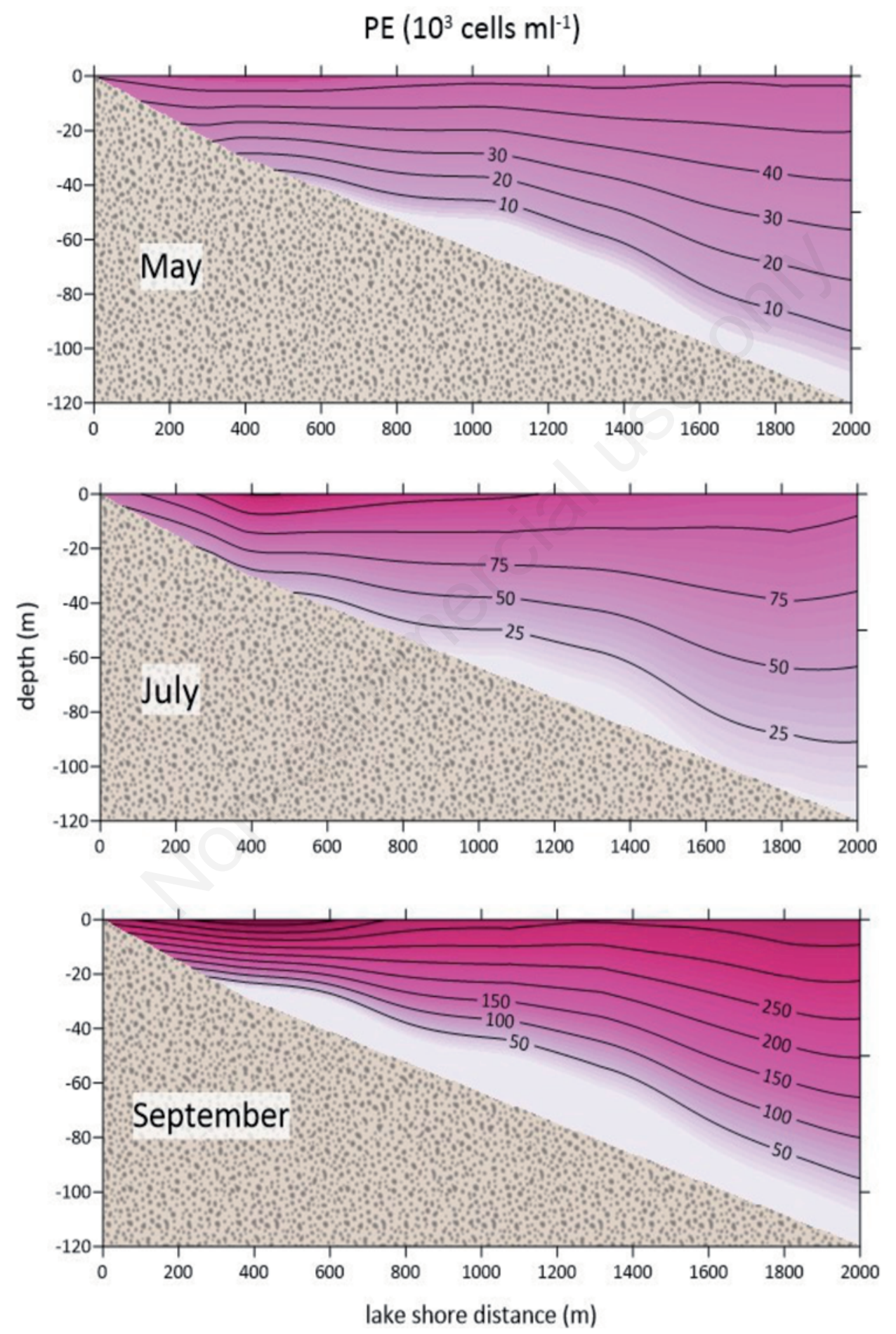

Fig. 7. Maps of the phycoerythrin-rich picocyanobacteria (PE) number along the transect of Lake Maggiore in May, July and September 2019. 


\section{Statistical analyses}

We tested the influence of sampling station and depth on the distribution of the various microbiological parameters and found that in all the tested cases depth (vertical distribution) was highly influential whereas the importance of stations (horizontal distribution) was not signifi- cant, with the exception of TOC in May and July and Chl and bacteria in July (Tab. 2S).

We found a significant correlation between TEP concentration and four phytoplankton groups measured with flow cytometry: phycocyanin and phycoerythrin picocyanobacteria (PC and $\mathrm{PE}$ ), bacteria, and eukaryotes (Tabs. 2 and 3S).

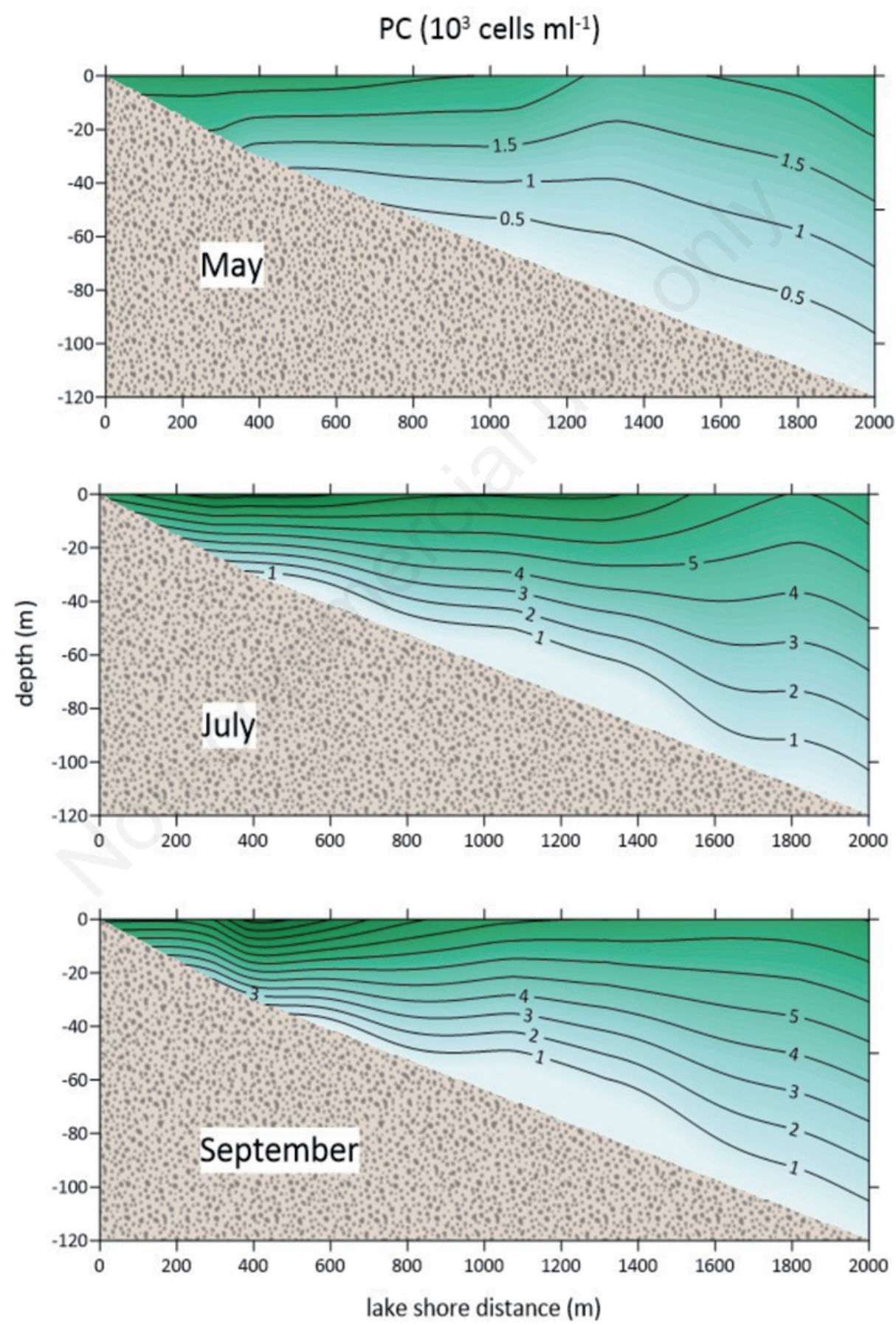

Fig. 8. Maps of the phycocyanin-rich picocyanobacteria (PC) along the transect of Lake Maggiore in May, July and September 2019. 
In particular, considering all the data, the correlation was significant only for PE; in May there was no significant correlation, in July there was a significant correlation with PC and eukaryotes, in September again there was a correlation with PE (Tab. 2). The regression of TEP versus PE was al- ways significant with an $\mathrm{R}^{2}$ of 0.406 in May, of 0.608 in July and of 0.673 in September (Fig. 15S).

The total Chl measured by FluoroProbe was significantly correlated to TEP both considering all the data together and by month (Tabs. 2 and 4S). Considering the

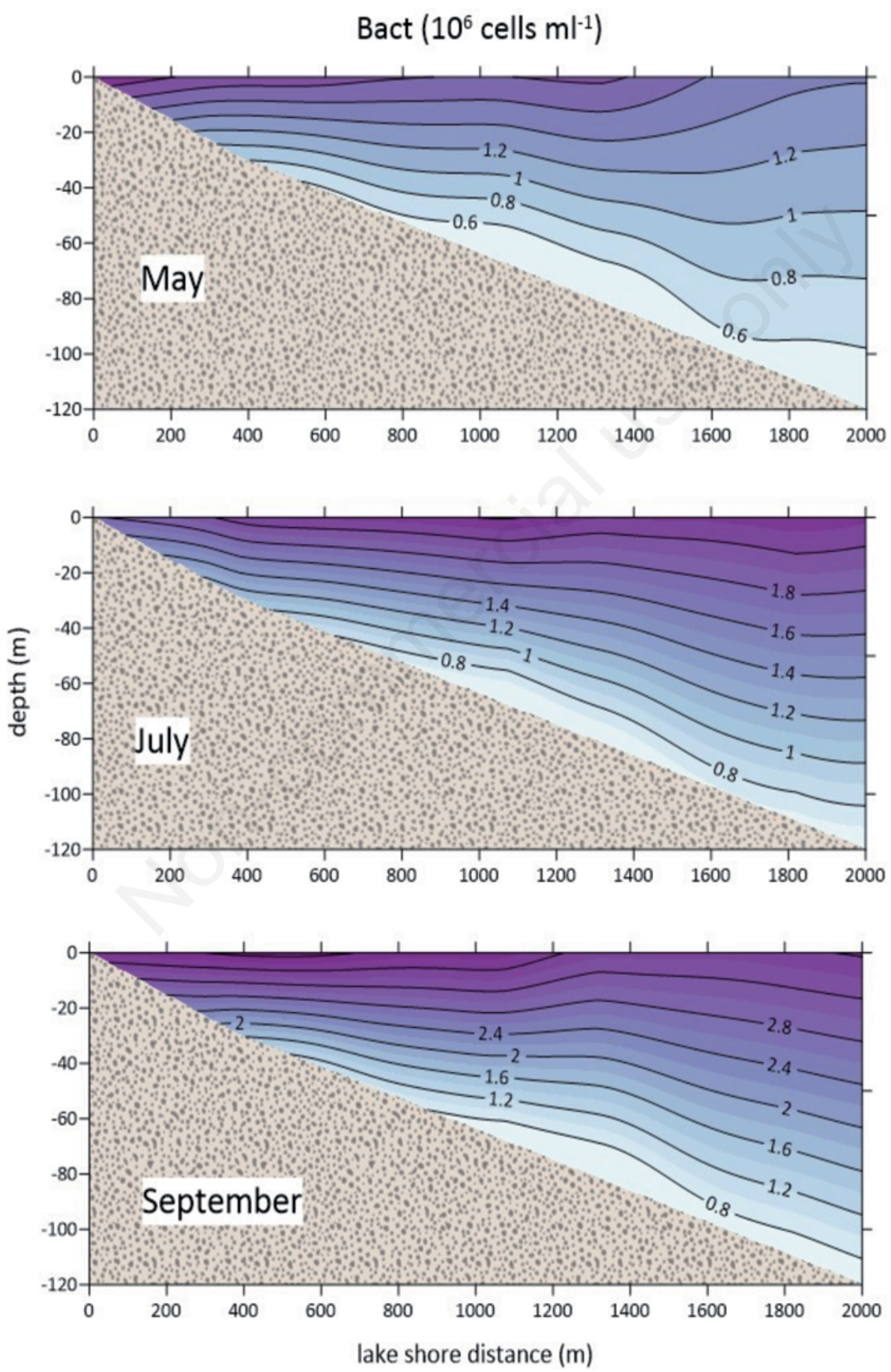

Fig. 9. Maps of the heterotrophic bacteria (Bact) number along the transect of Lake Maggiore in May, July and September 2019. 
FluoroProbe results of the different algal groups, TEP concentration was significantly correlated to brown algae in the whole study. In May, TEP was correlated to green algae biomass and in September with green and brown algae. In July there was no significant correlation (Tabs. 2 and 5S).

The CCA variables of organic carbon sources (TEP and TOC) and photosynthetic activity (Chl and PAR) clustered together and were strongly related to the different microbial groups; this pattern was clear for all ordinations except for July. On the other hand, TN, $\mathrm{N}-\mathrm{NO}_{3}$ and TP were found on the opposite side of the ordination indicating a weak relation (Fig. 10).

When considering all data $\mathrm{PC}$ was associated to $\mathrm{Chl}$ and temperature while PE was associated to TEP and temperature. The Eukaryotic algae (Euk) were associated in this ordination to $\mathrm{N}^{-\mathrm{NO}_{3}}$ and PAR (Tab. 6S). Bacteria were not strongly associated to variables in all ordinations. All the models obtained were significant $\left(\mathrm{p}<5 \times 10^{-4}\right)$ according to the ANOVA analysis (Tab. 7S). In May Euk and PE Synechococcus were associated to a cluster of the variables TEP, Total Chlorophyll (T Chl), temperature and PAR (Fig 10 A, Tab. 8S). In July, a clear relation was not found and Euk, PC and PE were only associated to pH (Fig. 10 B, Tab. 9S). In September PAR, T Chl, $\mathrm{pH}$ and TOC were associated to Euk and these same variables except for TOC, were related to PE (Fig. 10 C, Tab. 10S).

\section{DISCUSSION}

The limnological characteristics of the Borromeo basin, based on physical-chemical measurements, indicated: 1) the presence of a metalimnion in July and September that was not yet fully developed in May, 2) the persistence of conditions of oligotrophy with slightly higher concentrations of $\mathrm{Si}$ and $\mathrm{N}-\mathrm{NO}_{3}$ concentrations in May and subsequent decline due to diatoms growth, 3) a wide range of TEP concentrations from $35 \mu \mathrm{g} \mathrm{C} \mathrm{L}^{-1}$ in May to $236 \mu \mathrm{g} \mathrm{C} \mathrm{L}^{-1}$ in September, when foams appeared on the lake surface.

In this framework, the picture offered by the distribution maps of the different parameters in the Borromeo basin of Lake Maggiore revealed that, the horizontal heterogeneity, visible observing the distribution maps was not statistically significant for TEP and picocyanobacteria, compared to the vertical gradient that was always significant. Conversely, there was a significant horizontal TOC heterogeneity in May and July, and of Chl and bacteria in July, even at a lower extent respect to the vertical gradient (Tab. 2S). Therefore, the hypothesized horizontal heterogeneity of TEP concentrations between the littoral and pelagic zones, based on the observation of accumulated foams along the coast, was not found in the Borromeo basin of Lake Maggiore. Similarly, picocyanobacteria PE numbers were fairly evenly distributed horizontally, indicating that the littoral and pelagic zones worked in unison for microorganisms in this large lake.

However, TOC, a parameter that includes TEP and all the organisms expressed as carbon, $\mathrm{Chl}$ and bacteria presented some dissonance. Particularly for TOC, along with a vertical heterogeneity already highlighted (Bertoni et al., 2016), there was also a heterogeneity between the littoral and the pelagic zone, which showed a non-unidirectional concentration gradient. TOC accumulation in the littoral zone appeared more pronounced in September, when the maximum value of $2.3 \mathrm{mg} \mathrm{C} \mathrm{L}^{-1}$ was recorded, and there was a general increase of TOC concentrations, also evident in the pelagic zone.

From the distribution map of TEP, only in May two patches were visible: one in the pelagic and a smaller one in the littoral zone. This apparent horizontal heterogeneity was not significant, however, and this could be due to the possibility that patchiness of TEP is on a much finer scale with micro-hot spots of TEP production (Verdugo et al., 2004), not detectable by data analysis.

Tab. 2. P-values of the statistics of the linear models testing the effect of PE, PC cyanobacteria, eukaryotes (EUK), total Chlorophyll- $a$ (Chl), chlorophyll of the different algal groups (measured by FluoroProbe) on the concentration of TEP in the whole dataset and for each of the sampling dates.

\begin{tabular}{lcccc} 
TEP versus & Whole study & May & July & September \\
PC number & 0.3982 & 0.1750 & $\mathbf{0 . 0 0 7 3} * *$ & 0.9819 \\
\hline PE number & $\mathbf{0 . 0 0 1 0} * *$ & 0.1030 & 0.0678 & $\mathbf{0 . 0 1 3 9} *$ \\
\hline EUK number & 0.2660 & 0.6740 & $\mathbf{0 . 0 0 4 3} * *$ & 0.3817 \\
\hline Total Chl & $\mathbf{0 . 0 0 8 4 x 1 0 - - 2 * * *}$ & $\mathbf{0 . 0 0 2 8} * *$ & $\mathbf{0 . 0 0 0 1 \times 1 0 - - 6 * *}$ & $\mathbf{0 . 0 0 0 6 \times 1 0 - - 2} * * *$ \\
\hline Green & 0.2853 & $\mathbf{0 . 0 3 4 4} *$ & 0.2100 & $\mathbf{0 . 0 0 2 7} * *$ \\
\hline Cyano PE & 0.7630 & 0.6493 & 0.8220 & 0.5623 \\
\hline Brown & $\mathbf{0 . 0 0 0 2} * * *$ & 0.1230 & 0.2040 & $\mathbf{0 . 0 0 0 4 \times 1 0 - - 2} * * *$
\end{tabular}

Green: Chlorophyceae, Euglenophyceae, Prasinophyceae; Cyano PE: Cyanophyceae phycoerythryn-rich. Brown: Dinophyceae, Bacillariophyceae, Fragillariophyceae, Mediophyceae, Chrysophyceae; Cryptophytes: Cryptophyceae; $* 00.05 ; * *<0.01 ; * * *<0.001$. 
To our knowledge, this is the first paper analysing in detail the distribution of TEP, TOC, Chl of different algal groups and picoplankton number in a lake, by comparing vertical and horizontal distribution. On the other hand, studies on marine transects are more numerous and have compared zones of different hydrology. For example, in a north-south transect of the Atlantic Ocean (Zamanillo et al., 2019a) and in the Gulf of Cadiz (García et al., 2002), TEP distribution was studied and its heterogeneity was found to depend on phytoplankton mass and $\mathrm{Chl}$ in the first case and from hydrodynamic patterns in the latter, an area of upwelling and currents. Therefore, in the area with high disturbance the physical events were dominant on the biological effects.

As regards freshwater systems, a study of 32 north temperate and Mediterranean lakes showed a relationship between TEP and $\mathrm{Chl}$ and even very high concentrations

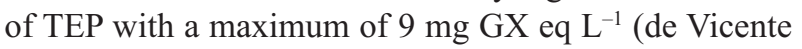
et al., 2010). In our study the maximum value was measured in September and, in terms of gum xanthan equivalents, was $1.44 \mathrm{mg} \mathrm{GX}$ eq $\mathrm{L}^{-1}$. However, it must be considered that Lake Maggiore is a deep, oligotrophic lake that can be hardly compared to a small eutrophic lake. The multivariate analysis (CCA) on all combined data showed that picoplanktonic communities ordinated towards higher TEP, Chl and temperature despite the single month data indicated different ordination of the environmental variables and microbial groups thus suggesting the presence of a dynamic net of relationships among microorganisms and environment.

Total Chl concentration presented a horizontal gradient, significantly heterogeneous in July with higher concentration in the mesopelagic station. The linear models indicated a strong relationship of total Chl with TEP concentration in all the months and this is in accordance with previous results in Lake Maggiore (Callieri et al., 2017) and in other freshwater and marine systems (de Vicente et al., 2010; Zamanillo et al., 2019b). The Chl profiles of the different algal groups indicated the dominance of brown algae in all three months. This algal group was also significantly correlated with TEP concentration considering all the data together, thus suggesting brown algae (Dynophyceae, diatoms: Bacillariophyceae, Fragillariophyceae, Mediophyceae; and Chrysophyceae) as the most
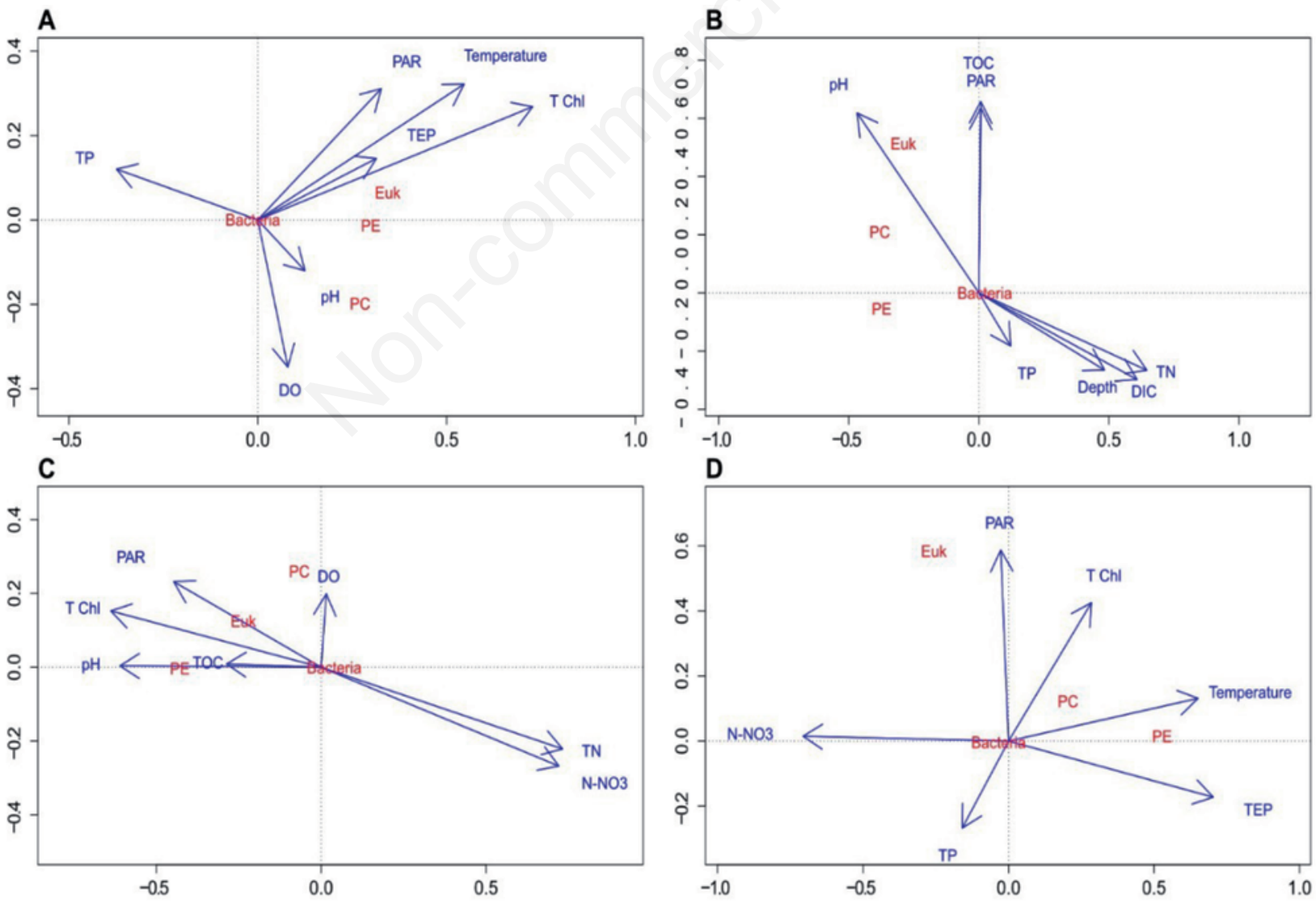

Fig. 10. Biplot of the Canonical Correspondence Analysis (CCA) of physical, chemical, and morphometric variables versus microbial groups. A) May; B) July; C) September; D) all data. 
important group producing TEP in Lake Maggiore. If we go deeper in the brown algae classification, looking at the data of the microscopic observations and those already published (Austoni et al., 2020) we see that in May/June they were composed by the pennate diatoms Fragilaria crotonensis and Asterionella formosa but also by the Crisophyceans Dinobryon divergens, Chrysochromulina parva and Mallomonas caudata (Austoni et al., 2020). The profiles in May showed that also green algae were important in all the stations and were dominant in the first three meters. In this period of the year green algae in Lake Maggiore were mainly composed by Sphaerocystis spp., Staurastrum spp. and Mougeotia sp. and were significantly correlated with TEP. Nevertheless, all the algae present in May and contributing to the highest biomass in Lake Maggiore during 2019 (2200 $\mathrm{g} \mathrm{L} \mathrm{L}^{-1}$ ) (Austoni et al., 2020) did not produce high TEP concentration, that in May reached the maximum of $100 \mu \mathrm{g} \mathrm{C} \mathrm{L}^{-1}$. Similarly, in July, when the highest Chl concentration was measured (8.13 $\left.\mu \mathrm{g} \mathrm{L}^{-1}\right)$, mainly due to pennate diatoms, the TEP concentration was low $\left(<100 \mu \mathrm{g} \mathrm{C} \mathrm{L}^{-1}\right)$. Only in September, when the phytoplankton community was not only composed of brown and green algae but also of cyanobacteria, a significant increase in TEP was observed, up to one order of magnitude higher $\left(910 \mu \mathrm{g} \mathrm{C} \mathrm{L}^{-1}\right)$. The brown algae, here constituted by centric diatoms like Cyclotella bodanica (Lindavia bodanica) and C. comensis and to a lesser extent to the pennate diatoms like $F$. crotonensis and $A$. formosa, were highly significantly correlated to TEP. The PE cyanobacteria, constituted in this month by colonial cyanobacteria like Microcystis aeruginosa, Aphanothece spp. and Aphanocapsa spp. together with a massive number of single cell and microcolonies of Synechococcus were significantly correlated with TEP. On the contrary, if we consider the Chl of the cyanobacteria instead of their number, we do not find a significant correlation, and hence cyanobacteria would appear not a good predictor of TEP. Colonial and single-cell Chroococcales have been found to produce a high TEP concentration compared to filamentous cyanobacteria in xenic cultures (Pannard et al., 2016).

In September, the increase in TEP concentrations was not supported by an equally impressive increase in Chl but by an increase in picocyanobacteria and bacteria number. The centric diatoms, which dominated this month, appear to be the main producers of TEP, albeit with a lower concentration of $\mathrm{Chl}$, together with a rich autotrophic and heterotrophic microflora.

Some diatoms and cyanobacteria can produce TEP particles during the decline of a bloom (Grossart et al., 1997; Passow, 2002a) but these evidences are mainly derived from studies on marine species like Phaeocystis pouchetii and Thalassiosira rotula and others (Passow and Wassmann, 1994; Grossart and Simon, 2007; Tab. 3 in Passow, 2002a). From our results the maximum PSII photochemical efficiency, termed $\mathrm{F}_{\mathrm{v}} / \mathrm{F}_{\mathrm{m}}$, indicates that in September the diatoms show the highest values, thus it is not likely that the population was in a senescence phase. Green algae and cyanobacteria resulted less photosynthetically efficient than diatoms with also very low $\mathrm{F}_{\mathrm{v}} / \mathrm{F}_{\mathrm{m}}$ values (0.2-0.4) whereas in general the mean value for these groups is 0.8 and 0.6 , respectively (Masojídek et al., 2010). Nevertheless, one must remember that the ratio $\mathrm{F}_{\mathrm{v}} / \mathrm{F}_{\mathrm{m}}$ expresses also a "taxonomic signature" which is superimposed to the physiological status (Suggett et al., 2009). In fact, it has been observed that $F_{v} / F_{m}$ can decrease in coincidence with an increase in cell size, with a changing from a cyanobacteria to diatoms dominated community (from smaller to larger cells) (Sosik and Olson, 2002). Therefore, the ratio $\mathrm{F}_{\mathrm{v}} / \mathrm{F}_{\mathrm{m}}$ represents a composite index of taxonomy and nutritional status.

The different TEP concentrations during the three months were particularly evident in September when TEP reached the highest values and when foam episodes started to occur on the entire lake surface (CIPAIS, CNR IRSA - Sede di Verbania, 2020). Other episodes of foam formation had previously occurred in Lake Maggiore in particular in 2007, 2008 and 2010 (Stefani et al., 2016). The foams were composed by lipids, proteins, monosaccharides probably derived from the polysaccharides exudated by algae and with natural surfactant properties. Considering the results of our work, it is likely that the foams formation was strictly connected to the TEP formation also mirroring its homogeneous distribution from the littoral to the pelagic zone, particularly during months of high TEP concentration. Therefore, the foams accumulation near the shore can be related more to wind transportation of matter brought to the surface by the Langmuir circulation than to foam generation restricted to the littoral zone (Stefani et al., 2016). Indeed, during the periods of foam presence the characteristic surface strips resulting from Langmuir circulation were often observed in Lake Maggiore. In 2007 and 2008 there was an exceptional diatom development of Tabellaria flocculosa that was considered the main actor of foam formation in those years (Stefani et al., 2016). We cannot exclude the importance of the cyanobacteria Dolichospermum lemmermannii and of the picocyanobacterium Synechococcus in TEP and foam formation present in those years (Callieri et al., $2014,2017)$ but not considered in the study by Stefani et al. (2016).

\section{CONCLUSIONS}

In the Borromeo basin of Lake Maggiore, the distribution of TEP was more uniform along the horizontal gradient, from littoral to pelagic zone, than along the vertical gradient from surface to bottom. This result is related to 
the predominantly algal origin of TEP and to its relation with the autotrophic microorganisms prevailing in the euphotic zone of the lake. However, sporadic phenomena of horizontal heterogeneity were observed, especially of TOC, bacteria and Chl. This study confirms, for the first time, that TEP concentrations can reach very high values in oligotrophic lakes such as Lake Maggiore. The maximum value of $1.44 \mathrm{mg} \mathrm{GX} \mathrm{eq} \mathrm{^{-1 }}$ was measured in September 2019, in concomitance with an episode of foam appearance. TEP can be considered as one of the drivers of foams and its study in the field, combined with satellite maps of foams distribution on the whole lake surface, could be of some help in predicting potential accumulation zones. The significant relationship between TEP and $\mathrm{Chl}$ is confirmed in this study and the algal group mostly related to TEP is that of brown algae, particularly diatoms, and in May of Chlorophyceae. Cyanophyceae were not significantly correlated with TEP when considering Chl signatures, however, when analysing the number of picocyanobacteria, they were significantly correlated with TEP. Along with a high number of picocyanobacteria, which in September were present in the form of microcolonies and aggregates, there was also a very high number of bacteria, which could play a considerable role in direct or indirect TEP formation.

\section{REFERENCES}

Alldredge AL, Passow U, Haddock HD, 1998. The characteristics and transparent exopolymer particle (TEP) content of marine snow formed from thecate dinoflagellates. J. Plankton Res. 20:393-406.

Alldredge AL, Passow U, Logan BE, 1993. The abundance and significance of a class of large, transparent organic particles in the ocean. Deep Sea Res. Part I Oceanogr. Res. Pap. 40:1131-1140.

Ambrosetti W, Barbanti L, Sala N, 2003. Residence time and physical processes in lakes. J. Limnol.62:1-15.

American Public Health Association, American Water Works Association, Water Environment Federation, 2012. Standard Methods for the Examination of Water and Wastewater. Washington: American Public Health Association: 1120 pp.

Agenzia per la Protezione dell'Ambiente e per i Servizi Tecnici, Istituto di Ricerca sulle Acque - Consiglio Nazionale delle Ricerche, 2003. [Metodi analitici per le acque].[in Italian].APAT, Roma.

Austoni M, Eckert EM, Sforzi T, Marchetto A, 2020. [Struttura delle associazioni fitoplanctoniche nel Lago Maggiore e loro modificazioni in relazione a fattori di controllo trofici e climatici], p. 62-70 In: CNR IRSA (ed.), [Ricerche sull'evoluzione del Lago Maggiore. Aspetti limnologici. Programma triennale 2019-2021. Campagna 2019].[Book in Italian]. Commissione Internazionale per la protezione delle acque italo-svizzere.

Berman-Frank I, Rosenberg G, Levitan O, Haramaty L, Mari X, 2007. Coupling between autocatalytic cell death and trans- parent exopolymeric particle production in the marine cyanobacterium Trichodesmium. Environ. Microbiol. 9:1415-1422.

Berman-Frank I, Spungin D, Rahav E, Van Wambeke F, TurkKubo K, Moutin T, 2016. Dynamics of transparent exopolymer particles (TEP) during the VAHINE mesocosm experiment in the New Caledonian lagoon. Biogeosciences 13:3793-3805.

Bertoni R, Bertoni M, Morabito G, Rogora M, Callieri C, 2016. A non-deterministic approach to forecasting the trophic evolution of lakes. J. Limnol. 75:242-252.

Bertoni R, Callieri C, Corno G, Rasconi S, Caravati E, Contesini M, 2010. Long-term trends of epilimnetic and hypolimnetic bacteria and organic carbon in a deep holo-oligomictic lake. Hydrobiologia 644:279-287.

Bidle KD, 2015. The molecular ecophysiology of programmed cell death in marine phytoplankton. Annu. Rev. Mar. Sci. 7:341-375.

Bittar TB, Vieira AAH, 2010. Transparent exopolymer particles formation from capsules of Anabaena Spiroides (cyanobacteria) in culture1. J. Phycol. 46:243-247.

Callieri C, Amalfitano S, Corno G, Bertoni R, 2016. Grazinginduced Synechococcus microcolony formation: experimental insights from two freshwater phylotypes. FEMS Microbiol. Ecol. 92:fiw154.

Callieri C, Bertoni R, Contesini M, Bertoni F, 2014. Lake level fluctuations boost toxic cyanobacterial "oligotrophic blooms." PLoS One 9:e109526.

Callieri C, Bertoni R, Crippa E, Contesini M, Di Cesare A, Eckert EM, 2019a. [Il carbonio organico nel Lago Maggiore: tendenza evolutiva, origine e caratteristiche qualitative], p. 77-84 In: CNR IRSA (ed.), [Ricerche sull'evoluzione del Lago Maggiore. Aspetti Limnologici. Programma Triennale 2016-2018. Campagna 2018 e Rapporto Triennale 2016-2018].[Book in Italian]. Commissione Internazionale per la protezione delle acque italo-svizzere.

Callieri C, Corno G, Contesini M, Fontaneto D, Bertoni R, 2017. Transparent exopolymer particles (TEP) are driven by chlorophyll a and mainly confined to the euphotic zone in a deep subalpine lake. Inland Waters 7:118-127.

Callieri C, Cronberg G, Stockner JG, 2012. Freshwater picocyanobacteria: Single cells, microcolonies and colonial forms, p. 229-269 In: Whitton BA (ed.), Ecology of cyanobacteria II: Their diversity in space and time. Dordrecht: Springer.

Callieri C, Sathicq MB, Cabello-Yeves PJ, Eckert EM, Hernández-Avilés JS, 2019b. TEP production under oxidative stress of the picocyanobacterium Synechococcus. J. Limnol. 78:271-283.

CNR IRSA Verbania, 2020. [Ricerche sull'evoluzione del Lago Maggiore. Aspetti limnologici. Programma triennale 2019-2021. Campagna 2019].[Book in Italian]. Commissione Internazionale per la protezione delle acque italosvizzere: $110 \mathrm{pp}$.

Corzo A, Rodríguez-Gálvez S, Lubian L, Sangrá P, Martínez A, Morillo JA, 2005. Spatial distribution of transparent exopolymer particles in the Bransfield Strait, Antarctica. J. Plankton Res. 27:635-646.

de Vicente I, Ortega-Retuerta E, Mazuecos IP, Pace ML, Cole 
JJ, Reche I, 2010. Variation in transparent exopolymer particles in relation to biological and chemical factors in two contrasting lake districts. Aquat. Sci. 72:443-453.

Deng W, Cruz BN, Neuer S, 2016. Effects of nutrient limitation on cell growth, TEP production and aggregate formation of marine Synechococcus. Aquat. Microb. Ecol. 78:39-49.

Engel A, Thoms S, Riebesell U, Rochelle-Newall E, Zondervan I, 2004. Polysaccharide aggregation as a potential sink of marine dissolved organic carbon. Nature 428:929-932.

Flombaum P, Gallegos JL, Gordillo RA, Rincón J, Zabala LL, Jiao N, Karl DM, Li WKW, Lomas MW, Veneziano D, Vera CS, Vrugt JA, et al., 2013. Present and future global distributions of the marine cyanobacteria Prochlorococcus and Synechococcus. PNAS 110:9824-9829.

Fox J, Weisberg S, 2019. An R Companion to Applied Regression. Los Angeles: SAGE: 577 pp.

García CM, Prieto L, Vargas M, Echevarría F, García-Lafuente J, Ruiz J, Rubín JP, 2002. Hydrodynamics and the spatial distribution of plankton and TEP in the Gulf of Cádiz (SW Iberian Peninsula). J. Plankton Res. 24:817-833.

Gärdes A, Iversen MH, Grossart H-P, Passow U, Ullrich MS, 2011. Diatom-associated bacteria are required for aggregation of Thalassiosira weissflogii. ISME J. 5:436-445.

Gasol JM, Morán XAG, 2015. Flow cytometric determination of microbial abundances and its use to obtain indices of community structure and relative activity, p. 159-187 In: McGenity TJ, KN Timmis, and B Nogales (eds.), Hydrocarbon and lipid microbiology protocols. Berlin: Springer.

Genty B, Briantais J-M, Baker NR, 1989. The relationship between the quantum yield of photosynthetic electron transport and quenching of chlorophyll fluorescence. BBA - Gen. Subjects 990:87-92.

Grossart H-P, Berman T, Simon M, Pohlmann K, 1998. Occurrence and microbial dynamics of macroscopic organic aggregates (lake snow) in Lake Kinneret, Israel, in fall. Aquat. Microb. Ecol. 14:59-67.

Grossart H-P, Czub G, Simon M, 2006. Algae-bacteria interactions and their effects on aggregation and organic matter flux in the sea. Environ. Microbiol. 8:1074-1084.

Grossart H-P, Simon M, Logan BE, 1997. Formation of macroscopic organic aggregates (lake snow) in a large lake: The significance of transparent exopolymer particles, phytoplankton, and zooplankton. Limnol. Oceanogr. 42:1651-1659.

Grossart H-P, Simon M, 1998a. Significance of limnetic organic aggregates (lake snow) for the sinking flux of particulate organic matter in a large lake. Aquat. Microb. Ecol. 15:115-125.

Grossart H-P, Simon M, 1998b. Bacterial colonization and microbial decomposition of limnetic organic aggregates (lake snow). Aquat. Microb. Ecol. 15:127-140.

Grossart H-P, Simon M, 2007. Interactions of planktonic algae and bacteria: effects on algal growth and organic matter dynamics. Aquat. Microb. Ecol. 47:163-176.

Iuculano F, Mazuecos IP, Reche I, Agustí S, 2017. Prochlorococcus as a Possible Source for Transparent Exopolymer Particles (TEP). Front. Microbiol. 8:709.

Kuznetsova A, Brockhoff PB, Christensen RHB, 2017. lmerTest Package: Tests in Linear Mixed Effects Models. J. Stat. Soft. 82:1-26.

Liu L, Huang Q, Qin B, 2018. Characteristics and roles of Microcystis extracellular polymeric substances (EPS) in cyanobacterial blooms: a short review. J. Freshwater Ecol. 33:183-193.

Masojídek J, Vonshak A, Torzillo G, 2010. Chlorophyll Fluorescence Applications in Microalgal Mass Cultures, p. 277 292 In: DJ Suggett, O Prášil, and MA Borowitzka (eds.), Chlorophyll $a$ fluorescence in aquatic sciences: Methods and applications. Dordrecht: Springer.

Morabito G, Oggioni A, Austoni M, 2012. Resource ratio and human impact: how diatom assemblages in Lake Maggiore responded to oligotrophication and climatic variability. Hydrobiologia. 698:47-60.

Nissimov JI, Bidle KD, 2017. Stress, death, and the biological glue of sinking matter. J. Phycol. 53:241-244.

Oksanen J, Blanchet FG, Friendly M, Kindt R, Legendre P, McGlinn D, Minchin PR, O'Hara RB, Simpson GL, Solymos P, Stevens MHH, Szoecs E, Wagner H, 2019. Vegan: Community Ecology Package. R package version 2.5-6.

Ortega-Retuerta E, Duarte CM, Reche I, 2010. Significance of bacterial activity for the distribution and dynamics of transparent exopolymer particles in the Mediterranean Sea. Microb. Ecol. 59:808-818.

Ortega-Retuerta E, Reche I, Pulido-Villena E, Agustí S, Duarte CM, 2009a. Uncoupled distributions of transparent exopolymer particles (TEP) and dissolved carbohydrates in the Southern ocean. Mar. Chem. 115:59-65.

Ortega-Retuerta E, Passow U, Duarte CM, Reche I, 2009b. Effects of ultraviolet B radiation on (not so) transparent exopolymer particles. Biogeosciences 6:3071-3080.

Pannard A, Pédromo J, Bormans M, Briand E, Claquim P, Lagadeuc Y, 2016. Production of exopolymers (EPS) by cyanobacteria: impact on the carbon-to-nutrient ratio of the particulate organic matter. Aquat. Ecol. 50:29-44.

Passow U, 2000. Formation of transparent exopolymer particles, TEP, from dissolved precursor material. Mar. Ecol. Prog. Ser. 192:1-11.

Passow U, 2002a. Transparent exopolymer particles (TEP) in aquatic environments. Prog. Oceanogr. 55:287-333.

Passow U, 2002b. Production of transparent exopolymer particles (TEP) by phyto- and bacterioplankton. Mar. Ecol. Prog. Ser. 236:1-12.

Passow U, Alldredge AL, 1994. Distribution, size and bacterial colonization of transparent exopolymer particles (TEP) in the ocean. Mar. Ecol. Prog. Ser. 113:185-198.

Passow U, Alldredge AL, 1995. A dye-binding assay for the spectrophotometric measurement of transparent exopolymer particles (TEP). Limnol. Oceanogr. 40:1326-1335.

Passow U, Carlson CA, 2012. The biological pump in a high $\mathrm{CO}_{2}$ world. Mar. Ecol. Prog. Ser. 470:249-271.

Passow U, Wassmann P, 1994. On the trophic fate of Phaeocystis pouchetii (Hariot): IV. The formation of marine snow by P. pouchetii. Mar. Ecol. Prog. Ser. 104:153-161.

Pedrotti ML, Peters F, Beauvais S, Vidal M, Egge J, Jacobsen A, Marrasé C, 2010. Effects of nutrients and turbulence on the production of transparent exopolymer particles: a mesocosm study. Mar. Ecol. Prog. Ser. 419:57-69.

Prieto L, Navarro G, Cózar A, Echevarría F, García CM, 2006. Distribution of TEP in the euphotic and upper mesopelagic zones of the southern Iberian coasts. Deep Sea Res. Part II Top. Stud. Oceanogr. 53:1314-1328.

Prieto L, Sommer F, Stibor H, Koeve W, 2001. Effects of Plank- 
tonic Copepods on Transparent Exopolymeric Particles (TEP) Abundance and Size Spectra. J. Plankton Res. 23:515-525.

R Core Team, 2019. R: A language and environment for statistical computing. R Foundation for Statistical Computing, Vienna, Austria. Available from: https://www.R-project.org/ Rogora M, Buzzi F, Dresti C, Leoni B, Lepori F, Mosello R, Patelli M, Salmaso N, 2018. Climatic effects on vertical mixing and deep-water oxygen content in the subalpine lakes in Italy. Hydrobiologia 824:33-50.

Rogora M, Giacomotti P, Mosello R, Orrù A, Tartari GA, 2019. [Evoluzione stagionale e a lungo termine delle caratteristiche chimiche del Lago Maggiore e bilancio dei nutrienti a lago (azoto e fosforo)], p. 31-54 In: CNR IRSA. Sede di Verbania (ed.), [Ricerche sull'evoluzione del Lago Maggiore. Aspetti limnologici. Programma triennale 2016 2018. Campagna 2018 e rapporto triennale 2016-18].[Book in Italian]. Commissione Internazionale per la protezione delle acque italo-svizzere.

Salmaso N, Buzzi F, Capelli C, Cerasino L, Leoni B, Lepori F, Rogora M, 2020. Responses to local and global stressors in the large southern perialpine lakes: Present status and challenges for research and management. J. Great Lakes Res. 46:752-766.

Salmaso N, Mosello R, 2010. Limnological research in the deep southern subalpine lakes: synthesis, directions and perspectives. Adv. Oceanogr. Limnol. 1:5294.

Schreiber U, Schliwa U, Bilger W, 1986. Continuous recording of photochemical and non-photochemical chlorophyll fluorescence quenching with a new type of modulation fluorometer. Photosynth. Res. 10:51-62.

Schuster S, Herndl G, 1995. Formation and significance of transparent exopolymeric particles in the northern Adriatic Sea. Mar. Ecol. Prog. Ser. 124:227-236.

Silver MW, Shanks AL, Trent JD, 1978. Marine snow: Microplankton habitat and source of small-scale patchiness in pelagic populations. Science 201:371-373.
Sohm JA, Edwards BR, Wilson BG, Webb EA, 2011. Constitutive Extracellular Polysaccharide (EPS) production by specific isolates of Crocosphaera watsonii. Front. Microbiol. 2:229.

Sosik HM, Olson RJ, 2002. Phytoplankton and iron limitation of photosynthetic efficiency in the Southern Ocean during late summer. Deep Sea Res. Part I Oceanogr. Res. Pap. 49:11951216.

Stefani F, Salerno F, Copetti D, Rabuffetti D, Guidetti L, Torri G, Naggi A, Iacomini M, Morabito G, Guzzella L, 2016. Endogenous origin of foams in lakes: a long-term analysis for Lake Maggiore (northern Italy). Hydrobiologia 767:249-265.

Suggett DJ, Moore CM, Hickman AE, Geider RJ, 2009. Interpretation of fast repetition rate (FRR) fluorescence: signatures of phytoplankton community structure versus physiological state. Mar. Ecol. Prog. Ser. 376:1-19.

Thornton DCO, 2004. Formation of transparent exopolymeric particles (TEP) from macroalgal detritus. Mar. Ecol. Prog. Ser. 282:1-12.

Thornton DCO, Chen J, 2017. Exopolymer production as a function of cell permeability and death in a diatom (Thalassiosira weissflogii) and a cyanobacterium (Synechococcus elongatus). J. Phycol. 53:245-260.

Verdugo P, Alldredge AL, Azam F, Kirchman DL, Passow U, Santschi PH, 2004. The oceanic gel phase: a bridge in the DOM-POM continuum. Mar. Chem. 92:67-85.

Zamanillo M, Ortega-Retuerta E, Nunes S, Estrada M, Sala MM, Royer S-J, López-Sandoval DC, Emelianov M, Vaqué D, Marrasé C, Simó R, 2019a. Distribution of transparent exopolymer particles (TEP) in distinct regions of the Southern Ocean. Sci. Total Environ. 691:736-748.

Zamanillo M, Ortega-Retuerta E, Nunes S, Rodríguez-Ros P, Dall'Osto M, Estrada M, Montserrat Sala M, Simó R, $2019 b$. Main drivers of transparent exopolymer particle distribution across the surface Atlantic Ocean. Biogeosciences 16:733-749. 